\title{
Article \\ Performance of Two Seashore Paspalum (Paspalum vaginatum Sw.) Varieties Growing in Shallow Green Roof Substrate Depths and Irrigated with Seawater
}

\author{
Nikolaos Ntoulas * D and Ioannis Varsamos
}

Laboratory of Floriculture and Landscape Architecture, Department of Crop Science, Agricultural University of Athens, Iera Odos 75, 11855 Athens, Greece; varsamos.giannis@gmail.com

* Correspondence: ntoulas@aua.gr; Tel.: +30-210-529-4559

Citation: Ntoulas, N.; Varsamos, I. Performance of Two Seashore

Paspalum (Paspalum vaginatum Sw.) Varieties Growing in Shallow Green Roof Substrate Depths and Irrigated with Seawater. Agronomy 2021, 11, 250. https://doi.org/10.3390/ agronomy 11020250

Academic Editor: Christine E.

H. Coker

Received: 30 December 2020

Accepted: 27 January 2021

Published: 29 January 2021

Publisher's Note: MDPI stays neutral with regard to jurisdictional claims in published maps and institutional affiliations.

Copyright: (c) 2021 by the authors. Licensee MDPI, Basel, Switzerland. This article is an open access article distributed under the terms and conditions of the Creative Commons Attribution (CC BY) license (https:// creativecommons.org/licenses/by/ $4.0 /)$.

\begin{abstract}
The continuing decline in global drinking water reserves necessitates finding alternative water sources for turfgrass irrigation, especially in southern semi-arid Mediterranean countries. The aim of the present study was to evaluate the potential of using seawater for irrigating two varieties of seashore paspalum (Paspalum vaginatum Sw.), "Marina" and "Platinum TE", growing in shallow green roof substrates, and to determine their recuperative capacity after the termination of the salt stress period. The greenhouse study comprised of 48 lysimeters equipped with extensive green roof layering. Treatments included: (i) two substrate depths $(7.5 \mathrm{~cm}$ or $15 \mathrm{~cm})$ and (ii) three seawater irrigation regimes ( $7 \mathrm{~mm}, 15 \mathrm{~mm}$, or $45 \mathrm{~mm}$ every two days). Measurements included the determination of green turf cover (GTC) as well as the leaching fraction (LF) and leachate electrical conductivity $\left(\mathrm{EC}_{\mathrm{L}}\right)$ draining from the lysimeters. It was found that during the $46-\mathrm{d}$ salt stress period, none of the seawater irrigation regimes managed to maintain acceptable GTC levels for both seashore paspalum varieties. Increasing the green roof substrate depth from $7.5 \mathrm{~cm}$ to $15 \mathrm{~cm}$ resulted in GTC improvement. During the recovery period, the use of potable water as irrigation source improved GTC levels. After $40 \mathrm{~d}$ the recovery was complete since GTC exceeded $90 \%$ in all treatments for both varieties. Regression curves correlating GTC response to $\mathrm{EC}_{\mathrm{L}}$ can be used to estimate the leaching requirements of turfgrasses grown in shallow green roof systems when irrigated with saline water.
\end{abstract}

Keywords: seawater irrigation; seashore paspalum; green roof; substrate depth; green turf cover; leaching fraction; turfgrass management; salinity

\section{Introduction}

Green roofs are gaining increased worldwide recognition as an applicable strategy to improve the environmental quality of contemporary cities. Their benefits are numerous, including, but not restricted to, stormwater management, amelioration of the urban heat-island effect, building energy savings, noise and air pollution abatement, improvement of urban landscape aesthetics, and provision of new flora and fauna habitats [1]. Contemporary green roofs comprise a multi-layered system that partially or completely covers the rooftop of a building. From bottom-up, the multi-layered system includes: (a) a water-proofing and root-resistant membrane, (b) a protection layer for the water-proofing membrane with moisture retention capacity, (c) a drainage layer constructed either by porous media or by plastic undulated panels with additional water storage capacity, (d) a filtering sheet capable of separating liquid and solid phases, (e) a plant growth substrate comprised of lightweight materials, and (f) a plant vegetation layer [2]. Green roofs with a substrate depth smaller than $15 \mathrm{~cm}$ are classified as extensive types and their vegetation consists of low-maintenance, shallow-rooting, drought-resistant plants, such as succulents or other drought-tolerant plant species [3,4].

Although turfgrasses meet all three requirements for the desired plant uses within the urban environment, namely aesthetics, function, and recreation [5], they have rarely been 
evaluated on shallow green roof systems due to their increased water demands compared with succulents or other xerophytic plants, especially in arid and semi-arid climates [6]. To date, the limited number of studies that have investigated the performance and irrigation needs of various turfgrass species grown on shallow green roof systems are restricted to the Mediterranean region. Ntoulas et al. [7,8] evaluated the establishment, growth, and drought response of manillagrass (Zoysia matrella (L.) Merr. 'Zeon') on various green roof substrate types and two substrate depths $(7.5 \mathrm{~cm}$ and $15 \mathrm{~cm})$ under deficit irrigation. They reported higher green coverage and better physiological status of manillagrass when the substrate depth was $15 \mathrm{~cm}$ compared with a shallower substrate depth of $7.5 \mathrm{~cm}$. It was also determined that for manillagrass to retain more than $50 \%$ green coverage, the substrate moisture content (SMC) should be higher than 13\% $(v / v)$. Nektarios et al. [9] investigated tall fescue (Festuca arundinacea Schreb. 'Plantation') drought tolerance on shallow green roof systems and reported that, when irrigation was provided at $85 \%$ of evapotranspiration, substrate depth can be reduced from $15 \mathrm{~cm}$ to $7.5 \mathrm{~cm}$ without significantly stressing turfgrass plants. Ntoulas and Nektarios $[10,11]$ investigated the combined effects of six green roof substrates, placed in two substrate depths $(7.5 \mathrm{~cm}$ and $15 \mathrm{~cm})$ and managed under two deficit irrigation regimes, on the performance of seashore paspalum "Platinum TE" during the Mediterranean summer drought period. They reported that increasing green roof substrate depth from $7.5 \mathrm{~cm}$ to $15 \mathrm{~cm}$ may result in $40 \%$ water savings while SMC should be retained from 23.7 to $28.5 \%(v / v)$ to keep seashore paspalum within acceptable NDVI values.

In many arid or semi-arid areas critical freshwater shortages have resulted in the imposition of restrictions with regard to the use of potable water for irrigating landscape plants and turfgrasses [12]. In such cases, it is obvious that alternative water irrigation resources should be used for turfgrasses growing in shallow green roof systems. Water availability for green roof irrigation could be enhanced through the use of saline water [13], grey water [14], or recycled stormwater runoff [15].

The use of poor quality water for turfgrass irrigation has been reported to be successful by several researchers [16-19]. Saline irrigation water sources include saline groundwater, which may either be naturally saline or a result of salt leaching or due to seawater intrusion into the aquifer, brackish surface water, saline sewage effluent, and reclaimed or recycled water [20]. In rare cases, seawater has been proposed as an alternative source of turfgrass irrigation for short time periods [21]. Ocean water contains a high concentration of dissolved salts, mainly sodium chloride, and has a salinity of roughly $35,000 \mathrm{mg} \mathrm{L}^{-1}$. However, there are places where seawater salinity is higher, such as the Mediterranean Sea, which has a salinity of $38,000 \mathrm{mg} \mathrm{L}^{-1}$ or more [22].

In those rare cases that seawater is selected as the primary irrigation source, the selection of a highly salt-tolerant turfgrass species, such as seashore paspalum, is of immense importance in order to avoid salt-induced drought stress, growth hindrance, nutritional imbalances, and specific ion toxicities [20]. Seashore paspalum is a warm-season turfgrass species that is frequently used in the Mediterranean region [23]. It is well-adapted to adverse environmental conditions exhibiting increased tolerance to various abiotic stresses, including high salinity, drought, and wear [24-26]. Seashore paspalum ecotypes vary greatly with regard to their salt tolerance, while some of them have the capacity to survive in sand dunes along coastal sites subjected to seawater [27].

In order to minimize the adverse effects of increased salinity on turfgrass survival and growth whenever seawater is used for irrigation, a continuous leaching program is necessary in order to retain excess salts below the turfgrass rootzone [21]. According to Carrow et al. [28], leaching is the most important management practice for alleviating or preventing the stress of turfgrasses growing in salt-affected sites by preventing continuous salt accumulation. A leaching program involves irrigation applications that exceed the actual irrigation demands, based on evapotranspiration replenishment, and aims to maintain a high soil water potential and promote a consistent downward movement of salts [29]. Salinity control by leaching is much easier on sand-based growing media with 
high pore volume compared with fine-textured soils because of their increased infiltration and drainage rates [20].

During the last decade, green roof construction in the vicinity of coastal areas has been steadily increasing in several Mediterranean countries, mostly due to the development of recreation households and hotel resorts. In such cases, the potential use of seawater for irrigating turfgrass-covered green roofs could contribute to the conservation of valuable drinking water supplies. Green roofs are considered to be appropriate candidates for seawater irrigation due to the use of coarse-textured substrates. The constituents of green roof substrates include inorganic materials that are either coarse and/or possess significant internal porosity, such as pumice [30], crushed bricks or tiles [7], sand, zeolite [31], heat-expanded shale, clay or slate, perlite [32], and lava. Green roof substrates have been developed to exhibit increased infiltration rates [33], thus favoring the leaching of excess salts. Moreover, the green roof drainage layer could properly collect and safely dispose of the high salinity leachate, preventing contamination of potable groundwater or soil salinization.

Based on all the above-mentioned parameters, it would be important to determine the response of selected turfgrass species to seawater irrigation when grown in shallow green roof systems. The present study aimed to: (i) evaluate the green coverage alteration of two seashore paspalum varieties, "Marina" and "Platinum TE", when grown in two shallow green roof substrate depths and irrigated with seawater; (ii) determine threshold values of the leachate electrical conductivity $\left(\mathrm{EC}_{\mathrm{L}}\right)$, which will indicate the limits for adequate growth of seashore paspalum varieties when irrigated with seawater; and (iii) investigate the ability of seashore paspalum to recover its green turf cover (GTC), upon cessation of high salinity stress, through irrigation with potable water. The results of the present study are expected to provide guidance towards multiple stakeholders, such as municipalities, the green roof and turfgrass industry, developers, city planners, and the general public. In addition, the results of the current study are expected to serve as a decision-making tool regarding seashore paspalum irrigation with seawater or other similar water sources of increased salinity in shallow green roof systems found in the vicinity of coastal areas.

\section{Materials and Methods}

\subsection{Experimental Setup}

The study was conducted from 29 July 2016 until 31 October 2016 in the experimental glasshouse of the Laboratory of Floriculture and Landscape Architecture, Agricultural Univ. of Athens, Athens, Greece ( $37^{\circ} 59^{\prime} \mathrm{N}$ and $23^{\circ} 42^{\prime} \mathrm{E}, 30 \mathrm{~m}$ a.s.1.). It comprised of 48 polyvinyl chloride (PVC) lysimeters with $300 \mathrm{~mm}$ inner diameter (Figure 1), placed on leveled benches. A $10 \mathrm{~mm}$ diameter outflow opening was constructed at the bottom center of each lysimeter. A flexible hose was attached at the outlet leading the leachate into a $5 \mathrm{~L}$ tank stored beneath the lysimeter. Within the lysimeters, a complete layered simulation of an extensive green roof system was constructed (Figure 1). More specifically, a protection mat was placed at the bottom of the lysimeters, which was a synthetic cloth made of non-rotting synthetic fibers, having a $4 \mathrm{~mm}$ thickness, a dry weight of $0.50 \mathrm{~kg} \mathrm{~m}^{-2}$, and water permeability of $50 \mathrm{~mm} \mathrm{~s}^{-1}$, which was able to retain $3.6 \mathrm{~L} \mathrm{~m}^{-2}$ of water according to the manufacturer claims (VLS-500, DIADEM, Landco Ltd., Athens Greece). On top of the protection mat, a drainage board layer was placed, having a height of $25 \mathrm{~mm}$ and a weight of $1.35 \mathrm{~kg} \mathrm{~m}^{-2}$ (DiaDrain-25H, DIADEM, Landco Ltd., Athens, Greece). The drainage layer, which was made of recycled high-impact polystyrene, was equipped with water retaining troughs, having a water holding capacity of $11.8 \mathrm{~L} \mathrm{~m}^{-2}$ and openings for improving sub-surface aeration. The drainage layer was covered with a non-woven geotextile (VLF150, DIADEM, Landco Ltd., Athens, Greece) made of reinforced polypropylene, having a thickness of $1.2 \mathrm{~mm}$, a weight of $150 \mathrm{~g} \mathrm{~m}^{-2}$, and a water permeability of $105 \mathrm{~mm} \mathrm{~s}^{-1}$. The geotextile was used to prevent fine particle migration from the substrate towards the drainage layer, thus ensuring that the drainage layer would not clog and would function effectively. 


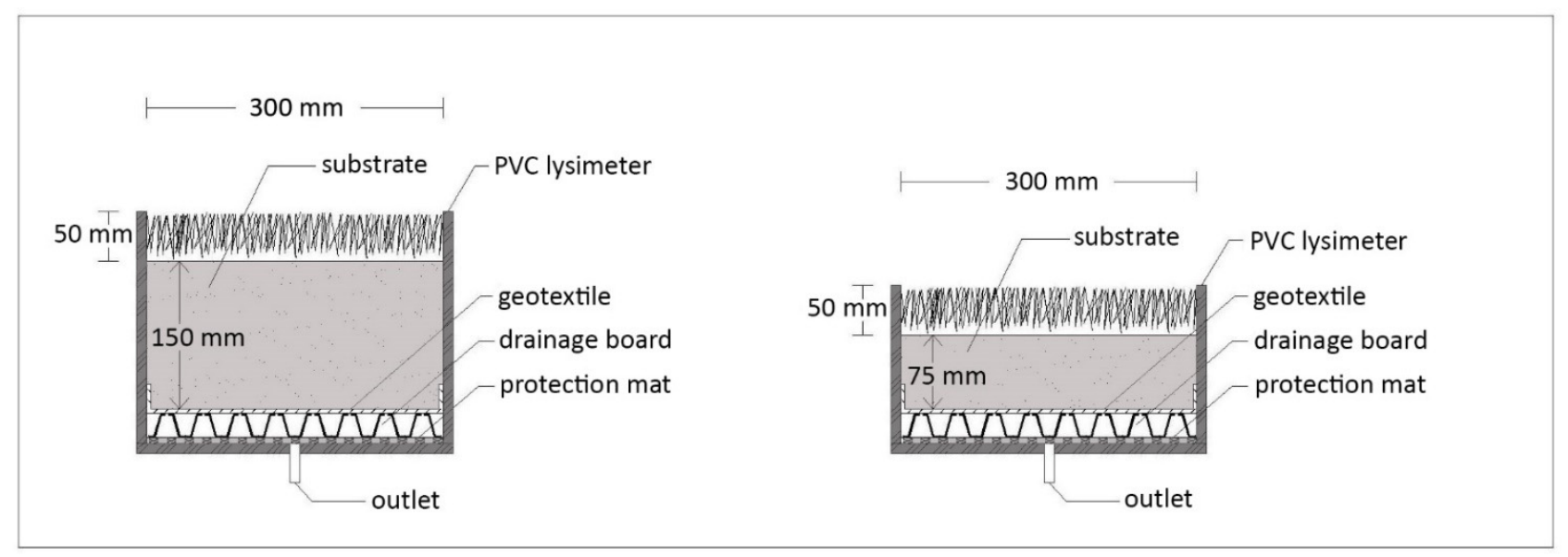

Figure 1. Construction detail of the experimental lysimeters indicating the different layers of the extensive green roof system in two substrate depths $(7.5 \mathrm{~cm}$ and $15 \mathrm{~cm})$.

The lysimeters were filled with a specialized and patented green roof substrate (Patent No. 1008610), which comprised $65 \%$ pumice, $15 \%$ thermally treated attapulgite clay, $15 \%$ grape marc compost, and 5\% clinoptilolite zeolite by volume. The physical and chemical properties of the substrate are presented in Table 1 . Half of the lysimeters had a substrate depth of $7.5 \mathrm{~cm}$, while the other half had a $15 \mathrm{~cm}$ substrate depth. Light compression and leveling were applied to the substrates after their placement into the lysimeters.

Table 1. Physical and chemical properties of the substrate, which comprised $65 \%$ pumice, $15 \%$ thermally treated attapulgite clay, $15 \%$ grape marc compost, and 5\% clinoptilolite zeolite by volume. Values represent the mean values of three replications wherever the standard error is provided $( \pm \mathrm{SE})$.

\begin{tabular}{|c|c|c|c|}
\hline \multirow{3}{*}{ Parameter } & \multirow{3}{*}{ Value $( \pm S E)$} & \multicolumn{2}{|c|}{ Mechanical Analysis } \\
\hline & & Particle Size & Percent Retained \\
\hline & & mm & $\%(w / w)$ \\
\hline $\mathrm{pH}$ & $7.2( \pm 0.02)$ & $9.5-6.3$ & 1.9 \\
\hline Electrical conductivity, $\mathrm{dS} \mathrm{m}^{-1}$ & $0.60( \pm 0.02)$ & $6.3-3.2$ & 23.6 \\
\hline Dry bulk density, $\mathrm{kg} \mathrm{L}^{-1}$ & $0.80( \pm 0.02)$ & $3.2-2.0$ & 17.3 \\
\hline Saturated bulk density, $\mathrm{kg} \mathrm{L}^{-1}$ & $1.30( \pm 0.05)$ & $2.0-1.0$ & 25.9 \\
\hline Weight at maximum field capacity, $\mathrm{kg} \mathrm{L}^{-1}$ & $1.20( \pm 0.03)$ & $1.0-0.25$ & 20.4 \\
\hline Maximum water holding capacity, $\%(v / v)$ & $54.2( \pm 1.65)$ & $0.25-0.05$ & 4.4 \\
\hline Total pore volume, $\%$ & $63.8( \pm 2.30)$ & $0.05-0.002$ & 5.4 \\
\hline Hydraulic conductivity, $\mathrm{mm} \cdot \mathrm{min}^{-1}$ & $7.62( \pm 0.67)$ & $<0.002$ & 1.1 \\
\hline
\end{tabular}

\subsection{Turfgrass Establishment}

The seashore paspalum varieties "Marina" and "Platinum TE" were established in the lysimeters on 16 June 2016 using washed sod. Each variety was established in 24 lysimeters, half of which had a substrate depth of $7.5 \mathrm{~cm}$, while the other half had a $15 \mathrm{~cm}$ substrate depth. After sodding, lysimeters were irrigated daily with potable water (EC of $0.3 \mathrm{dS} \mathrm{m}^{-1}$ ) until the initiation of seawater irrigation treatments (29 July 2016). During the establishment period, turfgrass sward was mowed at a height of $50 \mathrm{~mm}$ at weekly intervals with a handheld electric shear mower(Bosch ISIO3; Robert Bosch $\mathrm{GmbH}$, Gerlingen, Germany), and clippings were removed. Fertilization was applied as foliar applications of a water-soluble fertilizer (Nutrileaf, 20-20-20, Miller Chemical \& Fertilizer Corp., Hanover, PA, USA) at a rate of $5 \mathrm{~g} \mathrm{~L}^{-1} \mathrm{~m}^{-2}$ on 16 and 30 June 2016 and on 14 July 2016.

\subsection{Turfgrass Maintenance and Irrigation Regimes}

Seawater irrigation treatments were initiated on 29 July 2016 and ended on 13 September 2016, totaling $46 \mathrm{~d}$ of salinity stress. Two days before the initiation of the seawater 
irrigation period, all lysimeters were irrigated with ample potable water (EC of $0.3 \mathrm{dS} \mathrm{m}^{-1}$ ) to produce uniform substrate moisture conditions. From then on, both seashore paspalum varieties were irrigated with seawater (EC of $59.6 \mathrm{dS} \mathrm{m}^{-1}$ ) at the depths of $7 \mathrm{~mm}, 15 \mathrm{~mm}$, or $45 \mathrm{~mm}$ every second day.

The seawater used in the study was collected on a single day from Voula Beach, Attica, Greece $\left(37^{\circ} 50^{\prime} \mathrm{N}\right.$ and $\left.23^{\circ} 45^{\prime} \mathrm{E}\right)$ and was transported and stored in a protected tank inside the glasshouse. The amount of the collected seawater sufficed for the entire study period, and its chemical properties are listed in Table 2. Lysimeters were hand-irrigated with a watering can equipped with a nozzle to ensure even water distribution. In order to evaluate the recovery capacity of the two seashore paspalum varieties after the seawater irrigation stress period, irrigation with potable water was applied every second day at the depth of $7 \mathrm{~mm}$ until 31 October 2016, totaling $46 \mathrm{~d}$ of recovery.

Table 2. Chemical analysis of seawater used for turfgrass irrigation during the stress period (29 July13 September 2016).

\begin{tabular}{cc}
\hline Parameter & Value \\
\hline $\mathrm{pH}$ & 8.16 \\
Electrical conductivity $\left(25^{\circ} \mathrm{C}\right), \mathrm{dS} \mathrm{m}^{-1}$ & 59.6 \\
Total dissolved solids, $\mathrm{mg} \mathrm{L}^{-1}$ & 38,100 \\
Total hardness, $\mathrm{mg} \mathrm{CaCO}_{3} \mathrm{~L}^{-1}$ & 6543 \\
Sulphate $\left(\mathrm{SO}_{4}{ }^{2-}\right), \mathrm{mg} \mathrm{L}^{-1}$ & 2140 \\
Carbonate $\left(\mathrm{CO}_{3}{ }^{2-}\right), \mathrm{mg} \mathrm{L}^{-1}$ & 31.2 \\
Bicarbonate $\left(\mathrm{HCO}_{3}{ }^{-}\right), \mathrm{mg} \mathrm{L}^{-1}$ & 118 \\
Chloride $\left(\mathrm{Cl}^{-}\right), \mathrm{mg} \mathrm{L}^{-1}$ & 22,200 \\
Calcium $\left(\mathrm{Ca}^{2+}\right), \mathrm{mg} \mathrm{L}^{-1}$ & 461 \\
Magnesium $\left(\mathrm{Mg}^{2+}\right), \mathrm{mg} \mathrm{L}^{-1}$ & 1310 \\
Potassium $\left(\mathrm{K}^{+}\right), \mathrm{mg} \mathrm{L}^{-1}$ & 433 \\
Sodium $\left(\mathrm{Na}^{+}\right), \mathrm{mg} \mathrm{L}^{-1}$ & 10,800 \\
Copper $(\mathrm{Cu}), \mathrm{mg} \mathrm{L}^{-1}$ & $<0.04$ \\
Zinc $\left(\mathrm{Zn}^{2+}\right), \mathrm{mg} \mathrm{L}^{-1}$ & $<0.03$ \\
Iron $(\mathrm{Fe}), \mu g \mathrm{~L}^{-1}$ & 216 \\
Sodium adsorption ratio (SAR) & 58.2 \\
\hline
\end{tabular}

During the study, the experimental lysimeters were left unmoved due to minimal upward growth of the seashore paspalum varieties resulting from the increased salinity stress. Foliar fertilization was applied every two weeks with Nutrileaf, 20-20-20 watersoluble fertilizer at a rate of $5 \mathrm{~g} \mathrm{~L}^{-1} \mathrm{~m}^{-2}$.

\subsection{Greenhouse Climate Conditions}

Air temperature and relative humidity inside the greenhouse were monitored during the study using a HOBO U23 Pro v2 data logger (Onset Computer Corporation, Bourne, MA, USA), which was placed at a height of $1.80 \mathrm{~m}$ close to the lysimeters (Figure 2). The average temperature and relative humidity were $28.8^{\circ} \mathrm{C}\left( \pm 0.9^{\circ} \mathrm{C}\right)$ and $54.7 \%( \pm 6.7 \%)$, respectively, during the seawater irrigation stress period and $24.3^{\circ} \mathrm{C}\left( \pm 2.5^{\circ} \mathrm{C}\right)$ and $60.4 \%$ $( \pm 6.4 \%)$, respectively, during the recovery period. 


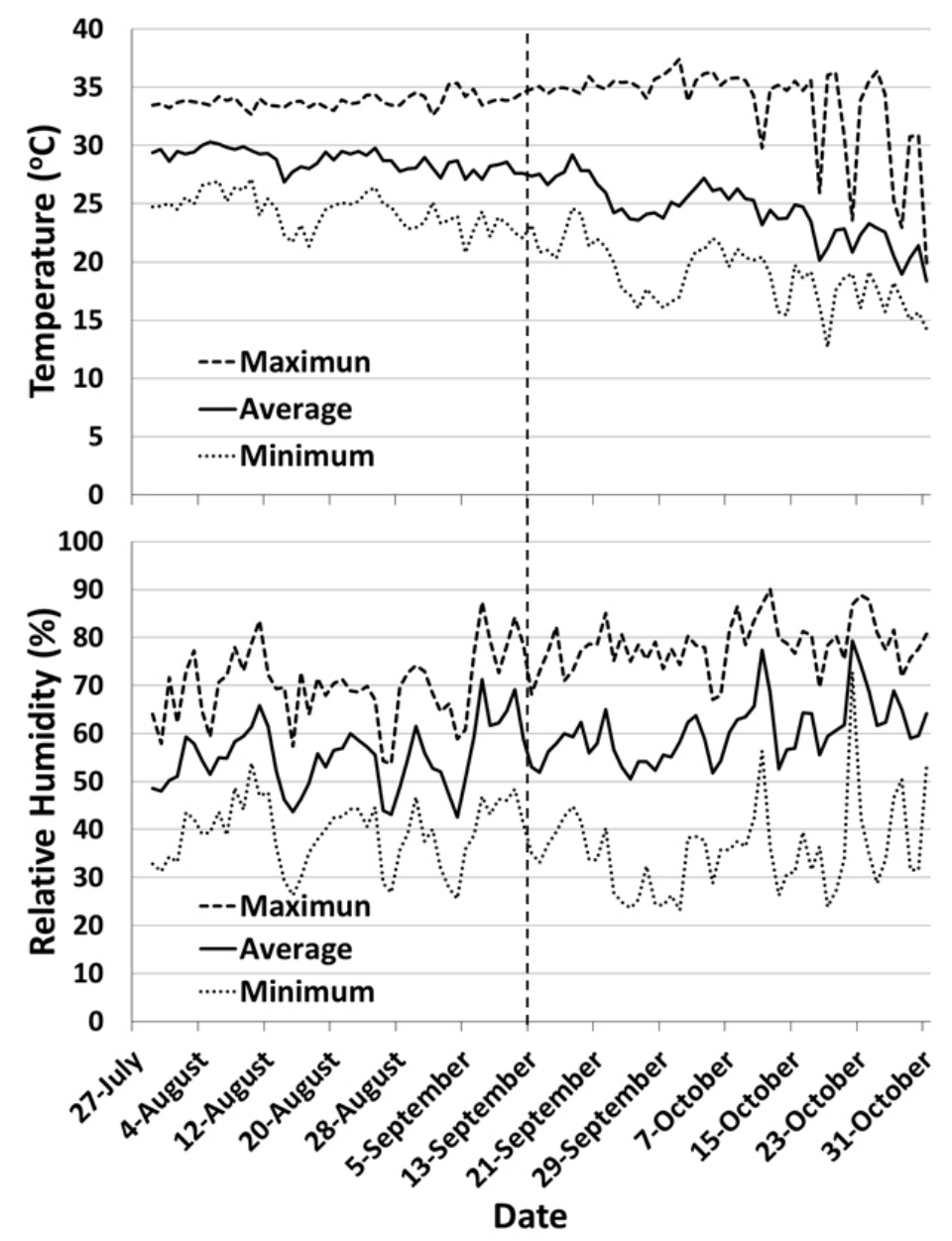

Figure 2. Glasshouse maximum, average, and minimum air temperature $\left({ }^{\circ} \mathrm{C}\right)$ and relative humidity (\%) for the whole duration of the study (29 July-31 October 2016). The dashed line separates the seawater irrigation stress period from the recovery period.

\subsection{Measurements}

Throughout the study, the GTC percentage was determined using digital images of each lysimeter taken on each irrigation date with a Canon IXUS 100 IS (Canon Europe Ltd., Uxbridge, UK) digital camera mounted on top of a sealed circular box $(30 \mathrm{~cm}$ in diameter $\times 45 \mathrm{~cm}$ in height), equipped with a circular fluorescent lamp (3000 K, 1200 lumens) on the upper, inner side of the box, which secured consistent lighting conditions throughout the image acquisition process. Camera settings remained constant during the study, comprising an aperture of F3.2, a focal length of $33 \mathrm{~mm}$, white balance set to fluorescent, and ISO sensitivity set to 200. The images were in JPEG format with a size of $1600 \times 1200$ pixels. Each image was cropped using Adobe Photoshop CS3 software (Adobe Systems Inc., San Jose, CA, USA) to remove any unwanted image portion. Green turf cover percentage was determined using the digital image analysis SigmaScan Pro Version 5.0 software (Systat Software Inc., San Jose, CA, USA) according to Richardson et al. [34].

The volume and salinity of the leachate, which was collected in tanks beneath each lysimeter, were determined every two days just before irrigation events. The collected leachate in the tanks referred to the previous irrigation application and was discarded after the determination of its volume and $\mathrm{EC}$. For $\mathrm{EC}_{\mathrm{L}}$ measurements, a handheld conductivity meter (CyberScan 200, Eutech Instruments Pte Ltd., Singapore) was used, which automatically corrected $\mathrm{EC}$ to $25^{\circ} \mathrm{C}$. The outflow runoff volume from each lysimeter was divided by the inflow irrigation water volume in order to estimate the leaching fraction (LF). 


\subsection{Experimental Design and Statistics}

The experimental design was multi-factorial and involved three factors: two seashore paspalum varieties ("Marina" and "Platinum TE"); two green roof substrate depths (7.5 cm or $15 \mathrm{~cm}$ ); and three seawater irrigation regimes $(7 \mathrm{~mm}, 15 \mathrm{~mm}$, or $45 \mathrm{~mm})$. The plot arrangement followed a completely randomized design and each treatment was replicated 4 times resulting in 48 lysimeters ( 2 seashore paspalum varieties $\times 2$ substrate depths $\times 3$ irrigation regimes $\times 4$ replications $=48$ lysimeters).

Due to statistical differences for GTC between varieties, during both stress $(p<0.001)$ and recovery $(p=0.0017)$ periods, data are presented separately for each seashore paspalum variety for all estimated parameters. Analysis of variance was performed on the collected data of GTC, $\mathrm{EC}_{\mathrm{L}}$, and LF for each seashore paspalum variety, during both stress and recovery periods, employing the JMP ${ }^{\circledR}$ ver.11 statistical software (SAS Institute Inc., Cary, $\mathrm{NC}$, USA), following the repeated measures analysis, with irrigation regimes being the main plot, substrate depths the subplot, and time (sampling dates) the sub-subplot. Treatment means were separated using Fisher's protected least significant difference (LSD) at a 0.05 probability level $(p<0.05)$.

The response of GTC to $\mathrm{EC}_{\mathrm{L}}$ for each seashore paspalum variety during the stress and recovery periods was analyzed using the segmented linear regression model. The two-segment linear regression model was:

$$
\begin{aligned}
& \mathrm{GTC}=s_{1} \times \mathrm{EC}_{\mathrm{L}}+c_{1}, \text { for } \mathrm{EC}_{\mathrm{L}}<X_{0} \\
& \mathrm{GTC}=s_{2} \times \mathrm{EC}_{\mathrm{L}}+c_{2}, \text { for } \mathrm{EC}_{\mathrm{L}} \geq X_{0},
\end{aligned}
$$

where $X_{0}$ is the breakpoint between the two line segments, $s_{1}$ and $s_{2}$ the slope of the two regression segments, and $c_{1}$ and $c_{2}$ the y-intercepts [35]. Regression analyses were accomplished using GraphPad Prism, version 6.01 for Windows (GraphPad Software Inc., San Diego, CA, USA).

\section{Results and Discussion}

\subsection{Irrigation with Seawater}

3.1.1. Leaching Fraction

During the stress period, when seawater was used for irrigation, the LF of the drainage water exhibited a similar fluctuation for both seashore paspalum varieties, "Marina" and "Platinum TE", and it was mostly affected by irrigation regime treatments and, to a lesser extent, by substrate depth (Table 3). Significant differences between the three irrigation regimes $(7 \mathrm{~mm}, 15 \mathrm{~mm}$, and $45 \mathrm{~mm}$ ) were evident on all sampling dates (Figure 3). The irrigation regime of $45 \mathrm{~mm}$ exhibited the highest LF compared with the other two irrigation regimes, with a mean value of 0.88 for "Marina" and 0.87 for "Platinum TE" (Table 3). The lowest LF values were recorded when irrigation with seawater was applied at the depth of $7 \mathrm{~mm}$ with mean values of 0.46 and 0.42 , respectively, while moderate values of LF were recorded at the $15 \mathrm{~mm}$ irrigation regime with an average of 0.74 for both varieties. 


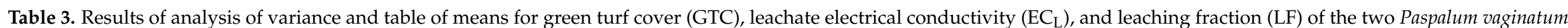

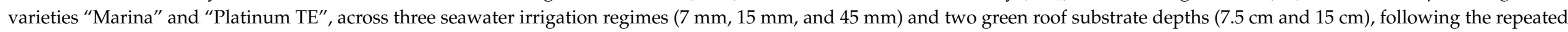

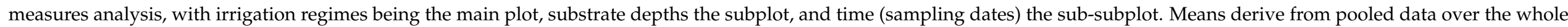

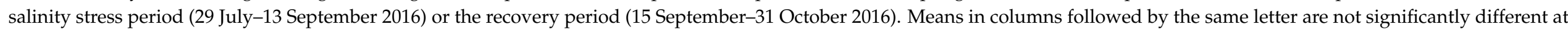
$p<0.05$ using Fisher's least significant difference (LSD).

\begin{tabular}{|c|c|c|c|c|c|c|c|c|c|c|c|c|}
\hline \multirow{3}{*}{ Source of Variation } & \multicolumn{6}{|c|}{ Stress Period } & \multicolumn{6}{|c|}{ Recovery Period } \\
\hline & \multicolumn{3}{|c|}{ Marina } & \multicolumn{3}{|c|}{ Platinum TE } & \multicolumn{3}{|c|}{ Marina } & \multicolumn{3}{|c|}{ Platinum TE } \\
\hline & GTC & $\mathrm{EC}_{\mathrm{L}}$ & LF & GTC & $\mathrm{EC}_{\mathrm{L}}$ & LF & GTC & $\mathrm{EC}_{\mathrm{L}}$ & LF & GTC & $\mathrm{EC}_{\mathrm{L}}$ & LF \\
\hline Irrigation regime (I) & $\mathrm{NS}^{+}$ & $* *$ & $* * *$ & NS & $* * *$ & $* * *$ & $* *$ & NS & NS & $* * *$ & $*$ & NS \\
\hline Substrate depth (D) & $*$ & $* * *$ & $* *$ & $*$ & $* * *$ & $*$ & NS & $* * *$ & NS & NS & $* * *$ & NS \\
\hline $\mathrm{I} \times \mathrm{D}$ & NS & $* * *$ & $* *$ & NS & $* *$ & * & NS & NS & NS & NS & NS & NS \\
\hline Sampling date $(\mathrm{T})$ & $* * *$ & $* * *$ & $* * *$ & $* * *$ & $* * *$ & $* * *$ & $* * *$ & $* * *$ & $* * *$ & $* * *$ & $* * *$ & $* * *$ \\
\hline $\mathrm{I} \times \mathrm{T}$ & $* * *$ & $* * *$ & $* * *$ & $* * *$ & $* * *$ & $* * *$ & $* * *$ & $* * *$ & NS & $* * *$ & $* * *$ & NS \\
\hline \multirow[t]{2}{*}{$\mathrm{I} \times \mathrm{D} \times \mathrm{T}$} & NS & $* * *$ & $*$ & NS & $* * *$ & * & NS & NS & NS & NS & NS & NS \\
\hline & \multicolumn{12}{|c|}{ Treatment means } \\
\hline \multicolumn{13}{|l|}{ Irrigation regime } \\
\hline $7 \mathrm{~mm}$ & $42.96 \mathrm{a}$ & $50.27 \mathrm{~b}$ & $0.46 \mathrm{c}$ & $54.79 \mathrm{a}$ & $48.25 \mathrm{c}$ & $0.42 \mathrm{c}$ & $48.98 \mathrm{~b}$ & $39.78 \mathrm{a}$ & $0.56 \mathrm{a}$ & $56.68 \mathrm{~b}$ & $45.35 \mathrm{a}$ & $0.54 \mathrm{a}$ \\
\hline $15 \mathrm{~mm}$ & $41.31 \mathrm{a}$ & $54.49 \mathrm{a}$ & $0.74 \mathrm{~b}$ & $47.29 \mathrm{a}$ & $53.16 \mathrm{~b}$ & $0.74 \mathrm{~b}$ & $52.63 \mathrm{~b}$ & $37.69 \mathrm{a}$ & $0.56 \mathrm{a}$ & $56.73 \mathrm{~b}$ & $42.02 \mathrm{ab}$ & $0.55 \mathrm{a}$ \\
\hline $45 \mathrm{~mm}$ & $46.25 \mathrm{a}$ & $55.36 \mathrm{a}$ & $0.88 \mathrm{a}$ & $50.82 \mathrm{a}$ & $55.39 \mathrm{a}$ & $0.87 \mathrm{a}$ & $64.24 \mathrm{a}$ & $36.45 \mathrm{a}$ & $0.53 \mathrm{a}$ & $70.40 \mathrm{a}$ & $39.60 \mathrm{~b}$ & $0.52 \mathrm{a}$ \\
\hline LSD & 6.48 & 2.79 & 0.03 & 9.02 & 1.00 & 0.04 & 7.63 & 4.16 & 0.04 & 4.68 & 3.48 & 0.03 \\
\hline \multicolumn{13}{|l|}{ Substrate depth } \\
\hline LSD & 4.92 & 1.20 & 0.02 & 8.09 & 1.78 & 0.01 & 4.04 & 2.34 & 0.02 & 5.13 & 2.10 & 0.02 \\
\hline
\end{tabular}

${ }^{*}$ Significant at the 0.05 probability level. ${ }^{* *}$ Significant at the 0.01 probability level. ${ }^{* * *}$ Significant at the 0.001 probability level. NS ${ }^{\dagger}$, nonsignificant at the 0.05 probability level. 

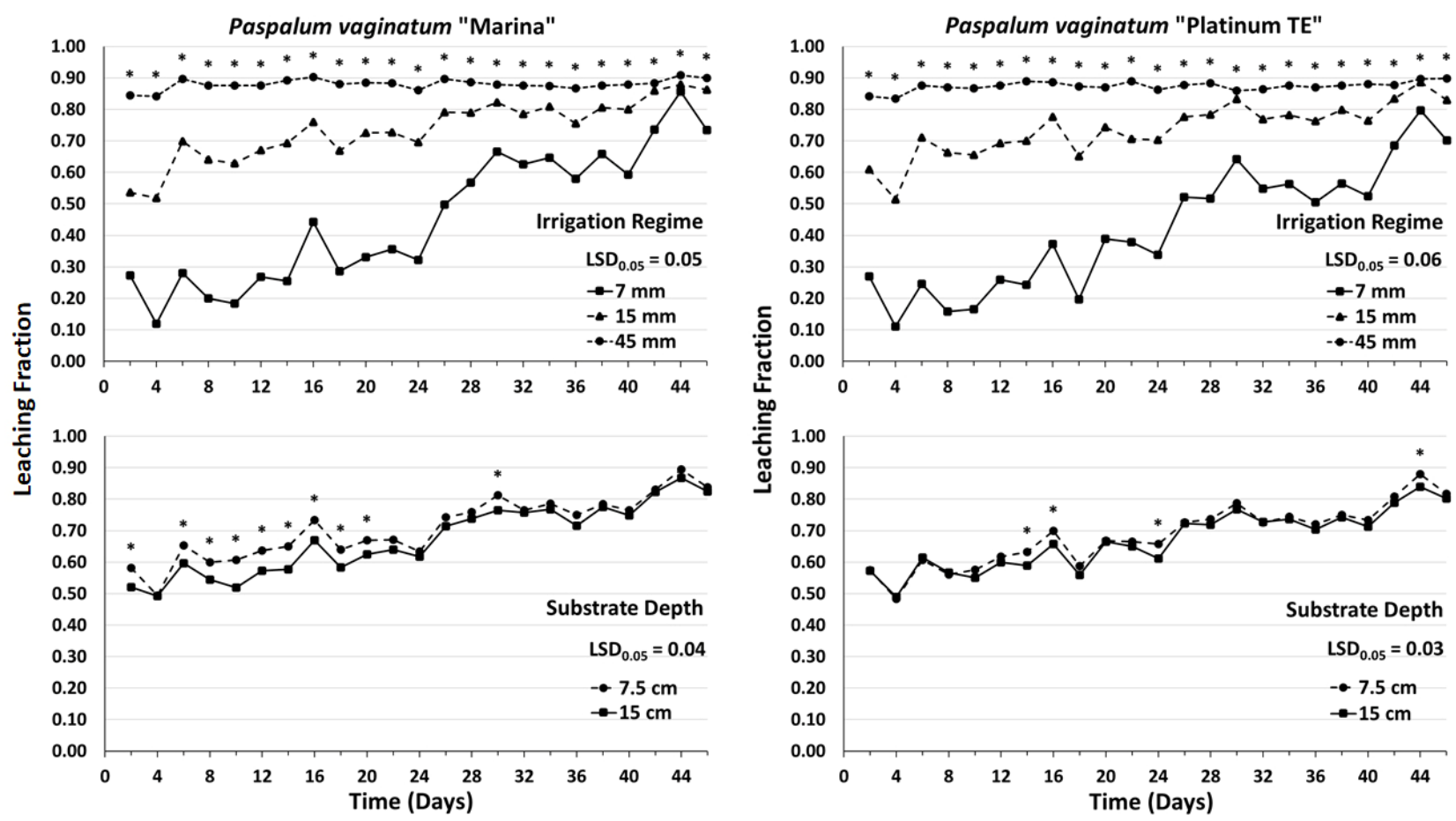

Figure 3. Leaching fraction of the two Paspalum vaginatum varieties "Marina" and "Platinum TE", as affected by seawater irrigation regimes $(7 \mathrm{~mm}, 15 \mathrm{~mm}$, or $45 \mathrm{~mm})$ and green roof substrate depth $(7.5 \mathrm{~cm}$ or $15 \mathrm{~cm})$ during the salinity stress period (29 July-13 September 2016). Values are the mean of 4 replications. Asterisks $\left.{ }^{*}\right)$ indicate significant differences in-between treatment means on a single sampling date, according to Fisher's least significant difference (LSD) at $p<0.05$ following the repeated measures model.

The LF of the two green roof substrate depths, $7.5 \mathrm{~cm}$ and $15 \mathrm{~cm}$, as well as that of the lower irrigation regimes of $7 \mathrm{~mm}$ and $15 \mathrm{~mm}$, exhibited an increasing trend (Figure 3). Given that the study was conducted under controlled environmental conditions and the air temperatures in the glasshouse remained relatively stable throughout the salinity stress period (Figure 2), the observed increase of LF values can be attributed to the fact that the turfgrasses were gradually induced into dormancy due to the imposed salinity stress caused by seawater irrigation. This is substantiated by GTC measurements. The induction into stress dormancy is expected to reduce the turf canopy transpiration rate, and subsequently water consumption, thus resulting in a gradual LF increase [36]. Similar results have also been observed in other plant species in shallow green roof substrates, although their physiology differs from that of turfgrasses. Moritani et al. [13], who evaluated the effect of salinity stress on evapotranspiration of a Sedum species grown under shallow green roof conditions, reported that, under saline irrigation, substrate moisture content was reduced at a lower rate compared with irrigation with potable water due to a decrease in ET resulting from salt stress.

From the beginning of the study and for $24 \mathrm{~d}$ after the initiation (DAI), the LF values for the irrigation regime of $7 \mathrm{~mm}$ remained relatively low and ranged from 0.10 to 0.45 for both varieties (Figure 3). By contrast, after 24 DAI, the LF values increased at a faster rate and reached values exceeding 0.70 during the last sampling dates. For the irrigation regime of $15 \mathrm{~mm}$, LF exhibited a different increase pattern which was more stable compared with the $7 \mathrm{~mm}$ irrigation regime. However, the $15 \mathrm{~mm}$ irrigation regime initiated at higher values, compared with the $7 \mathrm{~mm}$ regime, which ranged from 0.50 to 0.75 and increased to values that exceeded 0.80 towards the end of the stress period. Contrary to the $7 \mathrm{~mm}$ and the $15 \mathrm{~mm}$ irrigation regimes, the LF of the $45 \mathrm{~mm}$ irrigation regime remained almost stable and unchanged throughout the stress period while it was not affected by GTC reduction. 
Differences between the two substrate depths were less profound compared with the irrigation regime treatments. However, the two seashore paspalum varieties exhibited different responses, since in "Marina" the $7.5 \mathrm{~cm}$ depth provided higher LF than the deeper profile for 20 DAI (Figure 3). By contrast, the LF in "Platinum TE" was almost identical for both substrate depths and exhibited minimal differences on scattered sampling dates. In both varieties, whenever differences between the two substrate depths were observed, the shallow substrate of $7.5 \mathrm{~cm}$ always exhibited higher LF values compared with the $15 \mathrm{~cm}$ depth. This was caused by the increased substrate volume occupied by the $15 \mathrm{~cm}$ substrate depth, which retained larger amounts of water [37,38]. The average value of LF for the $15 \mathrm{~cm}$ substrate depth was 0.67 for both varieties, while, for the $7.5 \mathrm{~cm}$ depth, it was significantly higher and equal to 0.71 and 0.69 for "Marina" and "Platinum TE", respectively (Table 3). Accordingly, Soulis et al. [39] reported reduced runoff from lysimeters equipped with green roof system layering and sodded with tall fescue at a $16 \mathrm{~cm}$ substrate depth compared with a shallower depth of $8 \mathrm{~cm}$.

\subsubsection{Leachate Electrical Conductivity}

Statistical analysis revealed that green roof substrate depth and seawater irrigation regime significantly affected $\mathrm{EC}_{\mathrm{L}}$ for both seashore paspalum varieties "Marina" and "Platinum TE" (Table 3). The electrical conductivity of the leachate collected in tanks beneath the lysimeters started to increase after the initiation of seawater irrigation treatments, following a similar pattern for both varieties (Figure 4 ).
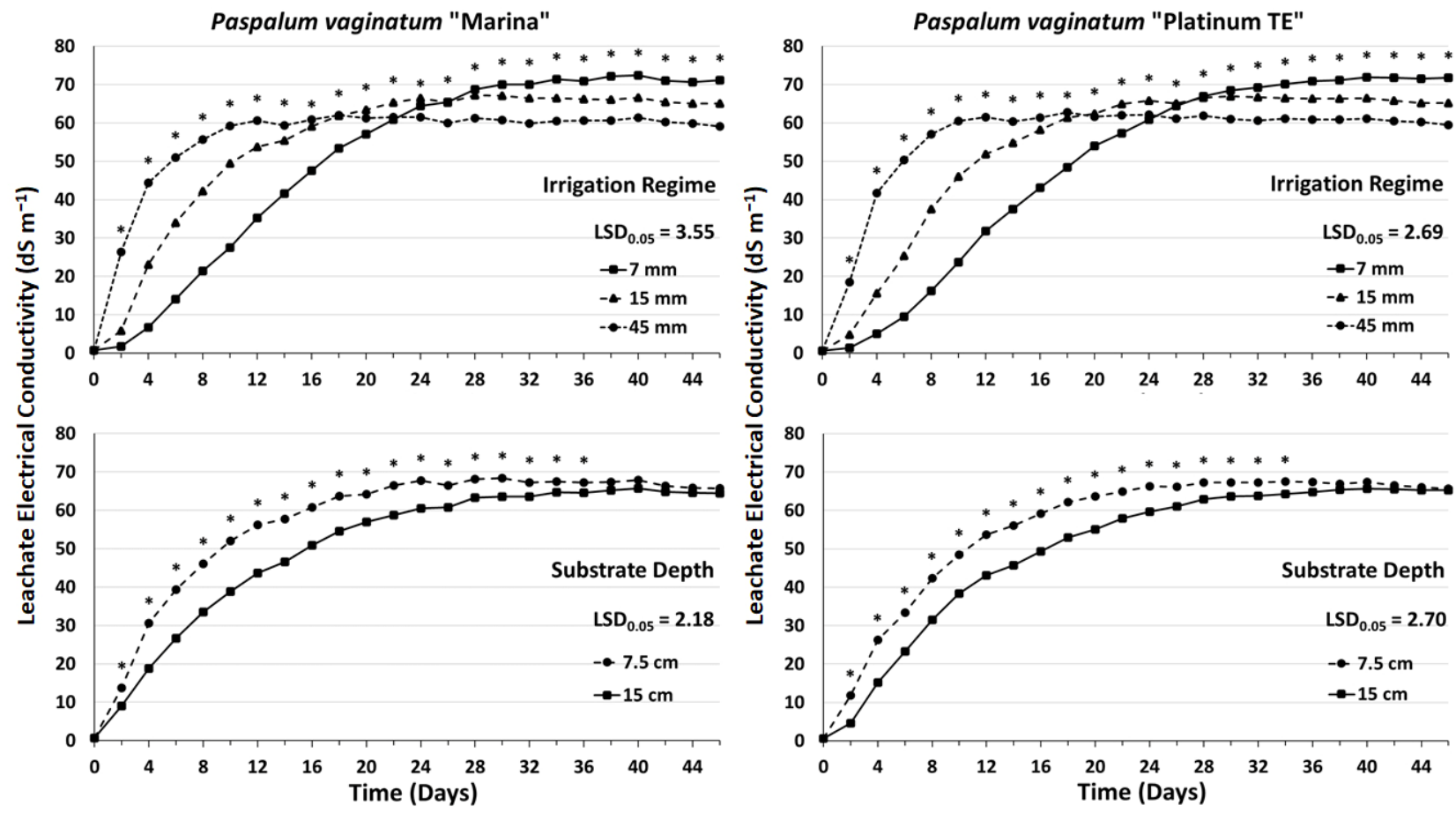

Figure 4. Leachate electrical conductivity $\left(\mathrm{dS} \mathrm{m}^{-1}\right)$ of the two Paspalum vaginatum varieties "Marina" and "Platinum TE", as affected by seawater irrigation regimes $(7 \mathrm{~mm}, 15 \mathrm{~mm}$, or $45 \mathrm{~mm})$ and green roof substrate depth $(7.5 \mathrm{~cm}$ or $15 \mathrm{~cm}) \mathrm{during}$ the salinity stress period (29 July-13 September 2016). Values are the mean of 4 replications. Asterisks $\left(^{*}\right)$ indicate significant differences in-between treatment means on a single sampling date, according to Fisher's least significant difference (LSD) at $p<0.05$ following the repeated measures model.

However, significant differences were evident with regard to the $\mathrm{EC}_{\mathrm{L}}$ increasing pattern between different irrigation regimes during the seawater stress period. During the first $12 \mathrm{DAI}$, the $45 \mathrm{~mm}$ irrigation regime exhibited the most abrupt increase rate and thus provided the highest $\mathrm{EC}_{\mathrm{L}}$ values compared with the other two seawater irrigation regimes (Figure 4). From 12 DAI until the end of the salinity stress study, the $\mathrm{EC}_{\mathrm{L}}$ values remained 
stable and ranged from 60 to $62 \mathrm{dS} \mathrm{m}^{-1}$, which was almost equal to the EC of the seawater (59.6 dS m $\mathrm{m}^{-1}$ ) that was used as the irrigation source. Contrary to the $45 \mathrm{~mm}$ irrigation regime, the $7 \mathrm{~mm}$ regime exhibited a slower but constant increase rate of $\mathrm{EC}_{\mathrm{L}}$ for $28 \mathrm{DAI}$. Equalization of $\mathrm{EC}_{\mathrm{L}}$ with that of the seawater, when irrigation was applied at $7 \mathrm{~mm}$, was recorded on 24 and 26 DAI for "Marina" and "Platinum TE", respectively. Subsequently, $\mathrm{EC}_{\mathrm{L}}$ continued to increase for both varieties reaching values that exceeded $70 \mathrm{dS} \mathrm{m}^{-1}$ on $36 \mathrm{DAI}$, while thereafter they ranged from 71 to $72 \mathrm{dS} \mathrm{m}-1$. When irrigation was applied at the $15 \mathrm{~mm}$ regime, $\mathrm{EC}_{\mathrm{L}}$ values for both varieties needed $18 \mathrm{DAI}$ to reach the seawater EC. Additional seawater irrigation applications resulted in further $\mathrm{EC}_{\mathrm{L}}$ increase for the next $10 \mathrm{~d}$, reaching values of $67.2 \mathrm{dS} \mathrm{m}^{-1}$ and $66.6 \mathrm{dS} \mathrm{m}^{-1}$ for "Marina" and "Platinum TE", respectively. From then on, $\mathrm{EC}_{\mathrm{L}}$ values remained relatively stable and ranged from 65 to $67 \mathrm{dS} \mathrm{m} \mathrm{m}^{-1}$. For the irrigation regimes of $7 \mathrm{~mm}$ and $15 \mathrm{~mm}$, the salinity of the drainage water achieved a steady-state condition after successive seawater irrigation events only when LF increased over 0.70 (Figure 3). A clear separation among stabilized values of $\mathrm{EC}_{\mathrm{L}}$ for the three irrigation regimes was revealed after 34 DAI for both varieties. The $\mathrm{EC}_{\mathrm{L}}$ values that were recorded towards the termination of the salinity stress period were approximately $10 \%$ lower than the values estimated using the steady-state salt balance equation: $\mathrm{EC}_{\mathrm{drainage} \text { water }}=\mathrm{EC}_{\text {irrigation water }} / \mathrm{LF}$ [40] based on the seawater $\mathrm{EC}$ and the LF recorded for the irrigation treatments. This deviation can be attributed to the fact that a portion of the drainage water was retained within the troughs of the green roof drainage board layer and the protection cloth, which were placed at the bottom of the lysimeters (Figure 1). Thus, there was a reduction in the obtained, compared with the expected, runoff water volume collected in the tanks [41], which led to a minor underestimation of the actual LF. It is obvious that whenever green roof irrigation is applied using seawater, leaching requirements are estimated to be extremely high in order for $\mathrm{EC}_{\mathrm{L}}$ to remain close to the salinity of seawater. In the opposite case, drainage water salinity is expected to increase dramatically. Similarly to our findings, El-Haddad \& Noaman [42] reported that when seashore paspalum, grown in $27 \mathrm{~cm}$ deep pots filled with a mixture of sand and peat, was irrigated for 10 weeks with seawater of $40 \mathrm{~g} \mathrm{~L}^{-1}$ at an LF of 0.25 , the drainage water salinity did not achieve a steady-salt balance during the study period, although it reached values more than $90 \mathrm{~g} \mathrm{~L}^{-1}$. When a $0.5 \mathrm{LF}$ was used, the salinity of drainage water reached a plateau of approximately $80 \mathrm{~g} \mathrm{~L}^{-1}$.

Concerning the two different green roof depths, the shallower substrate of $7.5 \mathrm{~cm}$ exhibited significantly higher $\mathrm{EC}_{\mathrm{L}}$ values than the $15 \mathrm{~cm}$ substrate depth soon after the initiation of seawater irrigation for both seashore paspalum varieties (Figure 4). Differences were apparent until 36 DAI for "Marina" and 34 DAI for "Platinum TE". Similar results were reported by Chowdhury \& Abaya [43], who evaluated the quality of runoff water from green roof systems covered with reed canary grass (Phalaris arundinacea L.) and irrigated with greywater. They reported that when the substrate depth was $30 \mathrm{~cm}$, the EC of the green roof effluent was about $20 \%$ higher than that collected from deeper profiles of $60 \mathrm{~cm}$. Equalization of $\mathrm{EC}_{\mathrm{L}}$ with the seawater EC occurred on $16 \mathrm{DAI}$ and $24 \mathrm{DAI}$ for the $7.5 \mathrm{~cm}$ and the $15 \mathrm{~cm}$ substrate depths, respectively, for both varieties. These results indicate that substrate depth constitutes a significant factor concerning the time required to achieve a stable salinity level by controlling LF in cases when green roofs are irrigated with saline water. After $\mathrm{EC}_{\mathrm{L}}$ equation with the seawater $\mathrm{EC}$, the $\mathrm{EC}_{\mathrm{L}}$ values exhibited a minimal increase in both substrate depths until the end of the salinity stress period and ranged from 62 to $68 \mathrm{dS} \mathrm{m}^{-1}$ for the $7.5 \mathrm{~cm}$ depth and from 60 to $65 \mathrm{dS} \mathrm{m} \mathrm{m}^{-1}$ for the $15 \mathrm{~cm}$ depth.

\subsubsection{Green Turf Cover}

Green coverage estimation has been reported as an appropriate criterion for assessing salinity tolerance since it provides a direct indication of salinity injury and can be easily assessed without being destructive for plant tissues [44,45]. The GTC percentage of both seashore paspalum varieties started to decline in all irrigation regimes and substrate depth treatments after the initiation of stress imposition using seawater as the irrigation source 
(Figure 5). Although significant differences were evident in-between irrigation treatment means on single sampling dates, the pooled GTC data were found to lack any significance for both varieties (Table 3). By contrast, the green coverage of "Marina" and "Platinum TE" was significantly affected by the green roof substrate depth. (Table 3).
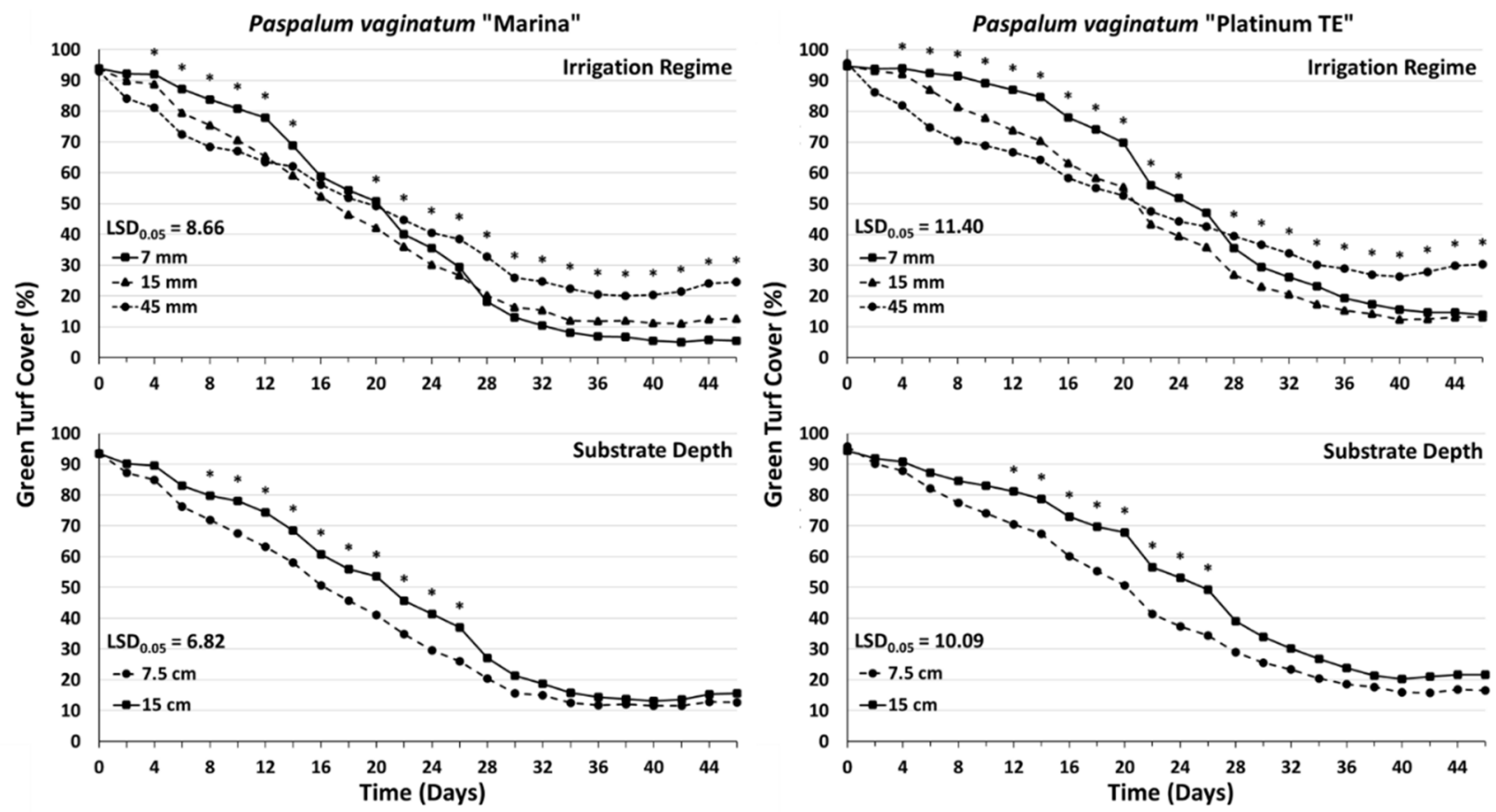

Figure 5. Green turf cover (\%) of the two Paspalum vaginatum varieties "Marina" and "Platinum TE", as affected by seawater irrigation regimes $(7 \mathrm{~mm}, 15 \mathrm{~mm}$, or $45 \mathrm{~mm})$ and green roof substrate depth $(7.5 \mathrm{~cm}$ or $15 \mathrm{~cm})$ during the salinity stress period (29 July-13 September 2016). Values are the mean of 4 replications. Asterisks $\left.{ }^{*}\right)$ indicate significant differences in-between treatment means on a single sampling date, according to Fisher's least significant difference (LSD) at $p<0.05$ following the repeated measures model.

On the first sampling dates, GTC reduction was more rapid when irrigation with seawater was applied at the depths of $15 \mathrm{~mm}$ and $45 \mathrm{~mm}$ for both seashore paspalum varieties. Significant differences were not evident between these two irrigation regimes, indicating a similar GTC reduction rate. In agreement with these results, Berndt [46] reported that a reduction in the visual quality of seashore paspalum "SeaDwarf" grown in pots containing sand was apparent from the first rating events, on 3 and 10 DAI of flood irrigation with seawater of $49.40 \mathrm{dS} \mathrm{m}^{-1}$. Moreover, Pompeiano et al. [47] observed leaf firing of seashore paspalum "SeaSpray" grown in pots suspended in tanks that contained a solution of $600 \mathrm{mM} \mathrm{NaCl}$, which is close to the salinity of seawater, only on $7 \mathrm{DAI}$ of their study.

Contrary to the higher irrigation regimes, at the beginning of the study, irrigation with $7 \mathrm{~mm}$ of seawater retained significantly higher GTC percentages, with these differences being more pronounced in "Platinum TE" (Figure 5). This is attributed to the fact that the lower irrigation regime of $7 \mathrm{~mm}$ retained drainage water and consequently rootzone salinity [12] at lower levels, thus imposing turfgrasses to reduced stress compared with the other two irrigation treatments (Figure 4). More specifically, when seawater irrigation was applied at the $7 \mathrm{~mm}$ regime, the GTC percentage of "Marina" started to decline on 6 DAI, requiring 10 DAI to reduce GTC below $80 \%$. "Platinum TE" exhibited a much slower reduction rate, retaining green coverage over $90 \%$ for $10 \mathrm{DAI}$, while GTC was reduced to values below $80 \%$ after 16 DAI.

Differences between the three irrigation regimes became insignificant 16 DAI for "Marina" and on 26 DAI for "Platinum TE" (Figure 5). This was caused by GTC overturn between irrigation treatments of $7 \mathrm{~mm}$ and $45 \mathrm{~mm}$ for both varieties. More specifically, 
when irrigation with seawater was applied at the regimes of $7 \mathrm{~mm}$ and $15 \mathrm{~mm}$, green coverage of the two seashore paspalum varieties continued to decline rapidly in an identical way, while the GTC of $45 \mathrm{~mm}$ irrigation regime exhibited a slower reduction rate, thus resulting in significantly higher values until the end of the stress period. This reverse response in green coverage was consistent with $\mathrm{EC}_{\mathrm{L}}$ variation over time among irrigation treatments, with the higher irrigation regime of $45 \mathrm{~mm}$ retaining $\mathrm{EC}_{\mathrm{L}}$ values close to the threshold salinity level of seawater (Figure 4). Instead, the other two irrigation regimes exceeded that threshold and imposed the turfgrasses to a comparatively increased salinity stress. The positive effect of increasing LF to salinity stress has been substantiated by El-Haddad and Noaman [42], who reported that under seawater irrigation of $40 \mathrm{mg} \mathrm{L}^{-1}$ salinity, seashore paspalum exhibited 19\% higher biomass production by increasing the LF from 0.25 to 0.5 .

On the last sampling date of the 46-d stress period, "Marina" recorded GTC values of $5.5 \%, 12.6 \%$, and $24.5 \%$, while "Platinum TE" recorded GTC values of $14.0 \%, 13.2 \%$, and $30.4 \%$ for the irrigation regimes of $7 \mathrm{~mm}, 15 \mathrm{~mm}$, and $45 \mathrm{~mm}$, respectively. Uddin et al. [48] reported that after 4 weeks of daily irrigation with seawater at a $13 \mathrm{~mm}$ depth, only $15 \%$ of leaf firing was observed in seashore paspalum grown in 15-cm deep pots filled with a mixture of river sand and peat $(9: 1 v / v)$ under greenhouse conditions. However, in their study, the seawater used had an EC of $48 \mathrm{dS} \mathrm{m}^{-1}$, while in the present study, seawater had a much higher EC of $59.6 \mathrm{dS} \mathrm{m}^{-1}$, imposing turfgrasses to more severe salinity stress. Shahba [49] reported that under the salinity level of $54 \mathrm{dS} \mathrm{m}^{-1}$, seashore paspalum cultivar "Salam" exhibited leaf firing of $80 \%$, followed by "Excalibur" with $90.5 \%$, while "Adalayd" exhibited 100\% leaf firing. Genetic-based variation in salt tolerance within seashore paspalums was also reported by Lee et al. [27], who evaluated shoot growth responses of 28 seashore paspalum ecotypes. The results of their study showed that ecotypes grown in a sea-salt amended nutrient solution of $41.1 \mathrm{dS} \mathrm{m}^{-1}$ presented leaf firing that ranged from $7 \%$ to $41 \%$.

Substrate depth significantly affected GTC reduction over time for both seashore paspalum varieties. The deeper substrate profiles of $15 \mathrm{~cm}$ improved GTC percentages compared with the $7.5 \mathrm{~cm}$ depth, with significant differences being evident from $8 \mathrm{DAI}$ for "Marina" and 12 DAI for "Platinum TE" onwards (Figure 5). However, after 26 DAI, differences between the two different substrate depths were negated and GTC reduction was completely halted on 38 DAI for both varieties. During the last five sampling dates of the stress period, GTC remained relatively stable for both substrate depths while percentages ranged from $11.6 \%$ to $15.6 \%$ for "Marina" and from 15.7 to $21.7 \%$ for "Platinum TE". The beneficial effect of deeper profiles could be attributed to their higher water storage capacity compared with the shallow substrate depths, which delayed the increase of $\mathrm{EC}_{\mathrm{L}}$ (Figure 4). It is also expected that deeper substrates favored increased root growth as an adaptation response of seashore paspalum to the increasing salinity, resulting in more efficient water and nutrient uptake [50] and, therefore, exhibiting better salinity tolerance and concomitantly recording lower leaf firing [51].

\subsection{Recovery Period}

\subsubsection{Leachate Electrical Conductivity}

Immediately after the termination of the salinity stress period, irrigation was resumed to potable water, which was applied every other day at a depth of $7 \mathrm{~mm}$ in order to investigate the recovery rate of the seashore paspalum varieties among treatments. During the recovery period, the $\mathrm{EC}_{\mathrm{L}}$ of "Platinum TE" was strongly affected by green roof substrate depth and, to a lesser extent, by seawater irrigation regimes applied during the stress period, while the $\mathrm{EC}_{\mathrm{L}}$ of "Marina" was only affected by substrate depth (Table 3). The mean LF during the recovery period ranged for both seashore paspalum varieties from 0.52 to 0.56 for all treatments (Table 3).

The $\mathrm{EC}_{\mathrm{L}}$ of "Marina" and "Platinum TE" started to decline on 6 DAI of the recovery period in all treatments (Figure 6). The two seashore paspalum varieties exhibited a differ- 
ent $\mathrm{EC}_{\mathrm{L}}$ response to the irrigation regimes applied during the stress period. Concerning the variety "Marina", the clear separation between irrigation regimes observed at the end of the stress period continued to exist on the first three sampling dates of the recovery period. From then on, differences between irrigation regimes became negligible and all irrigation treatments exhibited an identical $\mathrm{EC}_{\mathrm{L}}$ reduction rate. On the other hand, "Platinum TE" exhibited a higher $\mathrm{EC}_{\mathrm{L}}$ in $7 \mathrm{~mm}$ compared with the $45 \mathrm{~mm}$ irrigation regime, and these differences remained evident throughout the recovery period since all three irrigation treatments provided similar reduction rates (Figure 6).
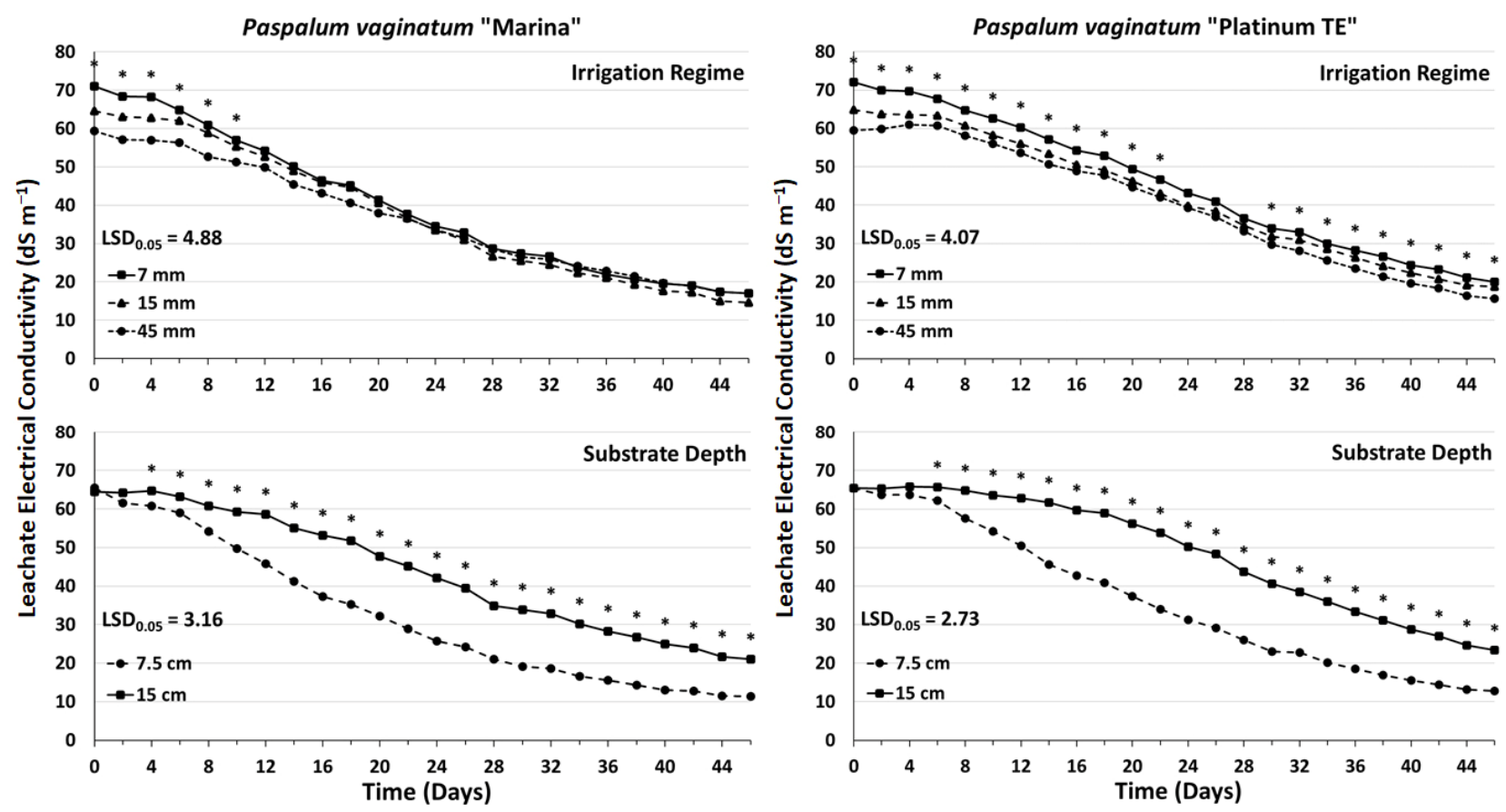

Figure 6. Leachate electrical conductivity $\left(\mathrm{dS} \mathrm{m}^{-1}\right)$ of the two Paspalum vaginatum varieties "Marina" and "Platinum TE" during the recovery period using $7 \mathrm{~mm}$ irrigation with potable water every other day (15 September-31 October 2016), as affected by seawater irrigation regimes during the salinity stress period $(7 \mathrm{~mm}, 15 \mathrm{~mm}$, or $45 \mathrm{~mm})$ and green roof substrate depth $(7.5 \mathrm{~cm}$ or $15 \mathrm{~cm})$. Values are the mean of 4 replications. Asterisks $\left(^{*}\right)$ indicate significant differences in-between treatment means on a single sampling date, according to Fisher's least significant difference (LSD) at $p<0.05$ following the repeated measures model.

Differences between substrate depths were more pronounced compared with those between irrigation treatments. The shallower profiles of $7.5 \mathrm{~cm}$ favored leaching of the salts accumulated in the substrate and exhibited a quicker $\mathrm{EC}_{\mathrm{L}}$ reduction rate compared with the substrate depth of $15 \mathrm{~cm}$, which recorded higher $\mathrm{EC}_{\mathrm{L}}$ values on almost all sampling dates. These differences were evident in both seashore paspalum varieties. At the end of the recovery period, which lasted for $46 \mathrm{~d}, \mathrm{EC}_{\mathrm{L}}$ was reduced from approximately $65 \mathrm{dS} \mathrm{m}^{-1}$ to $11.4 \mathrm{dS} \mathrm{m}^{-1}$ and $21.0 \mathrm{dS} \mathrm{m}^{-1}$ for "Marina" and $12.8 \mathrm{dS} \mathrm{m}^{-1}$ and $23.4 \mathrm{dS} \mathrm{m}^{-1}$ for "Platinum TE" for the substrate depths of $7.5 \mathrm{~cm}$ and $15 \mathrm{~cm}$, respectively.

\subsubsection{Green Turf Cover}

During the recovery period, the GTC of both seashore paspalum varieties was significantly affected by seawater irrigation regimes applied during the stress period, while substrate depth was indifferent (Table 3). Differences among treatments recorded at the end of the salinity stress period continued to exist during the recovery period for both varieties (Figures 5 and 7). During the first 8 DAI of the recovery period, GTC percentages remained relatively unchanged. However, a gradual increase of GTC was observed in all treatments after that point, exhibiting a similar recovery rate. As a result of the different GTC levels 
at the termination of the salinity stress period, higher GTC values were obtained with the irrigation regime of $45 \mathrm{~mm}$ compared with the other two irrigation regimes until 30 DAI of the recovery period. Between the two green roof substrate depths, no differences were observed on any sampling date concerning the GTC of both varieties (Figure 7), although deeper profiles of $15 \mathrm{~cm}$ recorded higher $\mathrm{EC}_{\mathrm{L}}$ values throughout the recovery period (Figure 6).
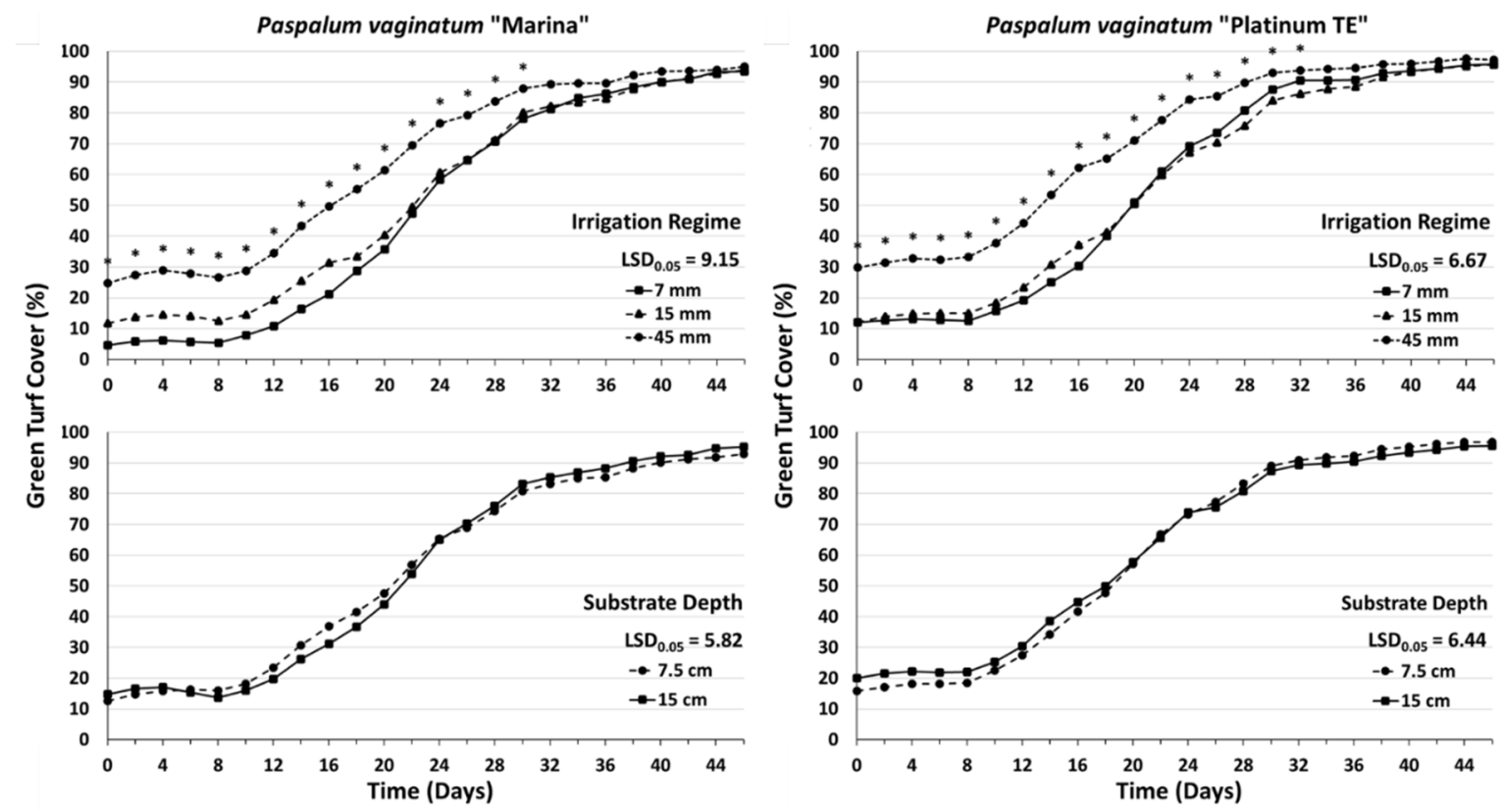

Figure 7. Green turf cover (\%) of the two Paspalum vaginatum varieties "Marina" and "Platinum TE" during the recovery period using $7 \mathrm{~mm}$ irrigation with potable water every other day (15 September-31 October 2016), as affected by seawater irrigation regimes during the salinity stress period $(7 \mathrm{~mm}, 15 \mathrm{~mm}$, or $45 \mathrm{~mm})$ and green roof substrate depth $(7.5 \mathrm{~cm}$ or $15 \mathrm{~cm})$. Values are the mean of 4 replications. Asterisks $\left.{ }^{*}\right)$ indicate significant differences in-between treatment means on a single sampling date, according to Fisher's least significant difference (LSD) at $p<0.05$ following the repeated measures model.

It is worth noting that after $40 \mathrm{~d}$ of recovery, all treatments, and for both varieties, presented GTC levels exceeding 90\%, indicating the ability of seashore paspalum varieties "Marina" and "Platinum TE" to fully recover after being irrigated with seawater for $46 \mathrm{~d}$ in shallow green roof systems. In accordance with our results, Pompeiano et al. [47] reported that seashore paspalum "SeaSpray" exhibited a green coverage reduction by $40 \%$ after $14 \mathrm{~d}$ of stress at salinity levels close to seawater, which was followed by a rapid and full recovery upon cessation of salinity stress and rewatering with distilled water for $7 \mathrm{~d}$, highlighting the ability of this turfgrass species to cope with severe salinity stress.

\subsection{Response of Green Turf Cover to Leachate Electrical Conductivity}

\subsubsection{Stress Period}

Regression between GTC and $\mathrm{EC}_{\mathrm{L}}$ was performed separately for the two substrate depths of $7.5 \mathrm{~cm}$ and $15 \mathrm{~cm}$ and each seashore paspalum variety, in an effort to determine the threshold $\mathrm{EC}_{\mathrm{L}}$ values that impact GTC during the salinity stress period using seawater for irrigation. Based on statistical analysis, the regression parameters between the two substrate depths for both varieties were not different at $p<0.05$ ( $p=0.2841$ for "Marina" and $p=0.0976$ for "Platinum TE"). Thus, data from both substrate depths were pooled into a single regression model for each variety (Figure 8). 

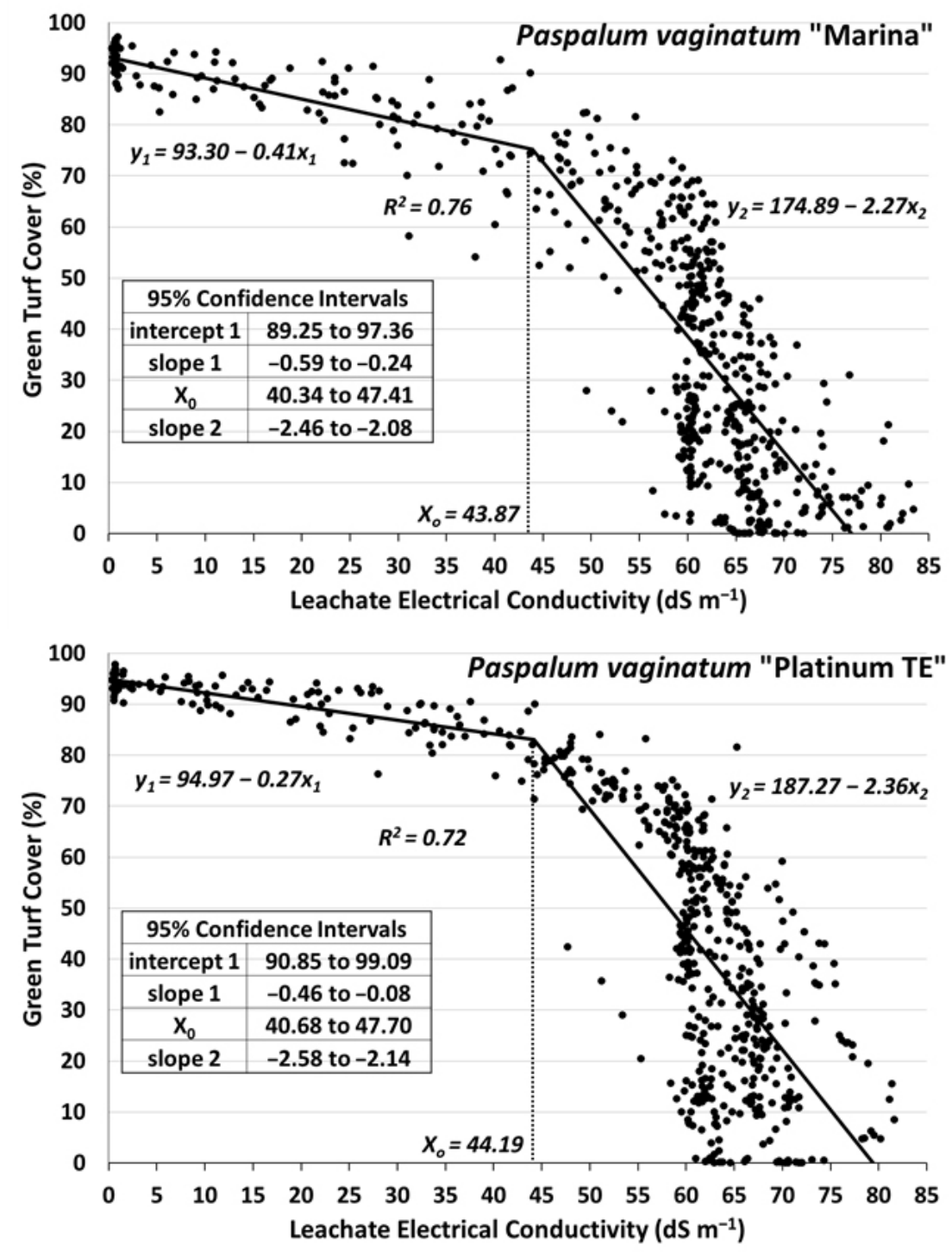

Figure 8. Two-segment linear regression models for the two Paspalum vaginatum varieties "Marina" and "Platinum TE" to determine green turf cover (\%) reduction resulting from leachate electrical conductivity $\left(\mathrm{dS} \mathrm{m}^{-1}\right)$ increase, when data from all treatments were pooled for the salinity stress period (29 July-13 September 2016).

It was found that the relationship between $\mathrm{GTC}$ and $\mathrm{EC}_{\mathrm{L}}$ was adequately described by a two-segment linear regression model, resulting in $R^{2}$ values equal to 0.76 and 0.72 for "Marina" and "Platinum TE", respectively (Figure 8). The regression model is similar to the yield response curve of agricultural crops to soil electrical conductivity $\left(E_{\mathrm{e}}\right)$ that has been proposed by Maas and Hoffman [52]. In their proposed model, crop relative growth or yield against increasing $\mathrm{EC}_{\mathrm{e}}$ was plotted as two linear sections. The first segment is a horizontal line depicting a lack of response to increasing salinity at low concentrations, while the slope of the second segment indicates decreases in yield per unit increase in $\mathrm{EC}_{\mathrm{e}}$ at higher salinity concentrations. The point where the two lines intersect is the threshold $\mathrm{EC}_{\mathrm{e}}$, which represents the maximum allowable soil salinity without yield reduction. However, in the current study, the first segment line was inclined rather than horizontal, which indicated that $\mathrm{EC}_{\mathrm{L}}$ increase resulted in moderate GTC reduction. The difference between expected and observed model parameters can be attributed to the fact that, in the current study, irrigation was applied solely using seawater with an EC of $59.6 \mathrm{dS} \mathrm{m}^{-1}$, which caused a rapid $\mathrm{EC}_{\mathrm{L}}$ increase and consequently a GTC reduction at the initiation of the stress period (Figures 4 and 5). Although there were no significant differences concerning regression 
slopes between the two varieties, "Marina" exhibited a trend of faster GTC reduction than "Platinum TE" in elevating salinity levels up to approximately $44 \mathrm{dS} \mathrm{m}^{-1}$, with estimated slope values of the first segment line of -0.41 and -0.27 , respectively.

The breakpoint between the two-line segments after which GTC reduction was accelerated, was estimated at $43.87 \mathrm{dS} \mathrm{m}^{-1}$ for "Marina" and $44.19 \mathrm{dS} \mathrm{m}^{-1}$ for "Platinum TE" and resulted in GTC values of $75.2 \%$ and $83.1 \%$, respectively. For salinity levels beyond the $\mathrm{EC}_{\mathrm{L}}$ thresholds, both varieties exhibited a similar GTC reduction, presenting slope values of the second segment line equal to -2.27 and -2.36 for "Marina" and "Platinum TE", respectively. According to the regression models, the $\mathrm{EC}_{\mathrm{L}}$, where $\mathrm{GTC}$ is expected to reduce to $50 \%$, is estimated at $55.0 \mathrm{dS} \mathrm{m}^{-1}$ for "Marina" and $58.2 \mathrm{dS} \mathrm{m}^{-1}$ for "Platinum TE".

\subsubsection{Recovery Period}

Contrary to the salinity stress period, the GTC of the two seashore paspalum varieties exhibited a different response to $\mathrm{EC}_{\mathrm{L}}$ for the two substrate depths during the recovery period. Therefore, segmented regressions of GTC against reducing $\mathrm{EC}_{\mathrm{L}}$ levels were performed separately for the two substrate depths of $7.5 \mathrm{~cm}$ and $15 \mathrm{~cm}$ for each seashore paspalum variety (Figure 9). For both varieties, reduction of $\mathrm{EC}_{\mathrm{L}}$ resulted in a faster GTC increase in the deeper profiles of $15 \mathrm{~cm}$ compared with the $7.5 \mathrm{~cm}$ substrate depth. The estimated slope of GTC increase for "Marina" grown in a $7.5 \mathrm{~cm}$ substrate depth was 1.63 , while it was significantly higher and equal to 2.02 when grown in a $15 \mathrm{~cm}$ depth. Similarly, the estimated slope for "Platinum TE" grown in a $7.5 \mathrm{~cm}$ substrate depth was 1.87 compared with the significantly higher 2.42 for the $15 \mathrm{~cm}$ substrate depth.
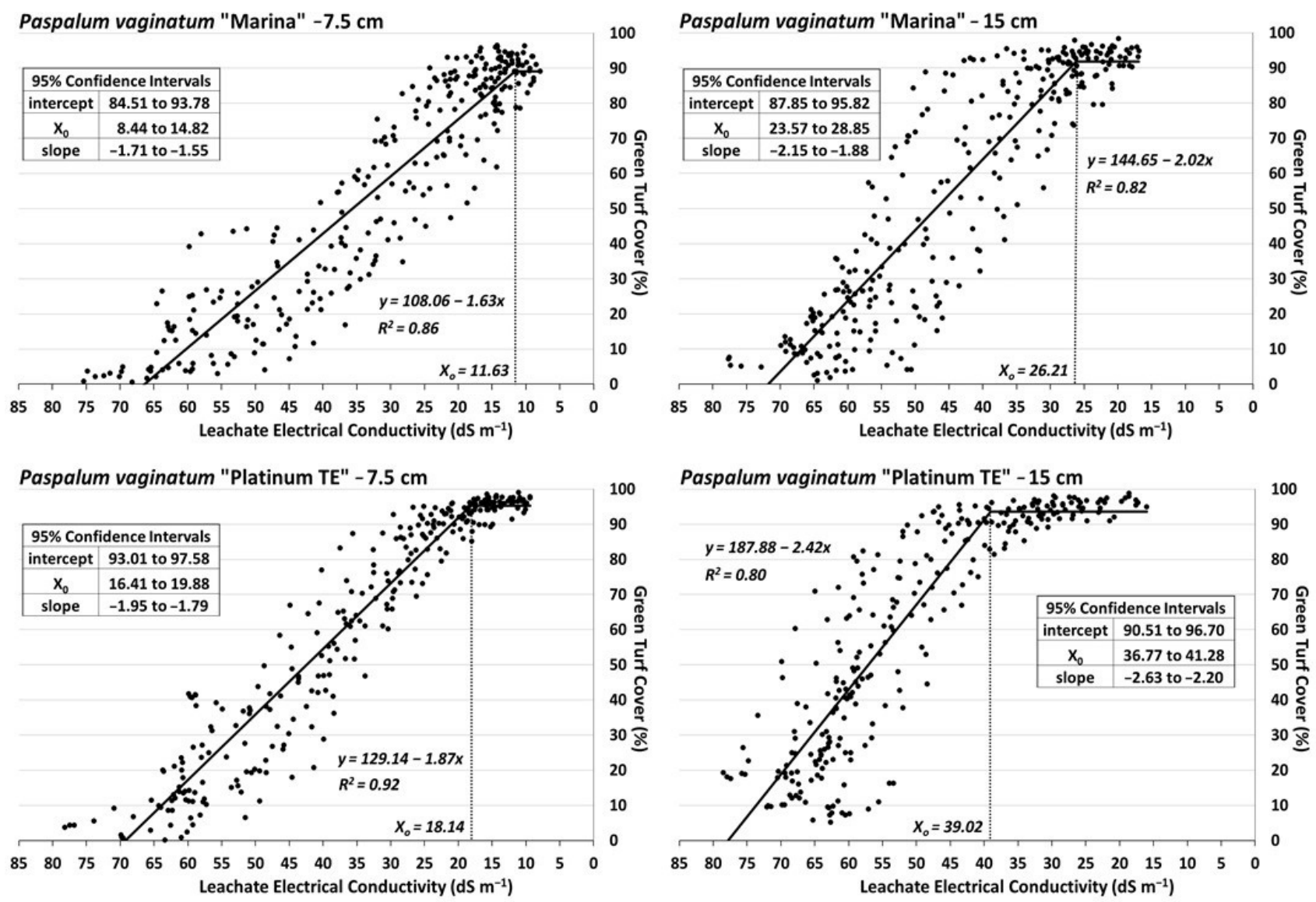

Figure 9. Two-segment linear regression models for the two Paspalum vaginatum varieties "Marina" and "Platinum TE" grown in two green roof substrate depths $(7.5 \mathrm{~cm}$ or $15 \mathrm{~cm})$ to determine green turf cover $(\%)$ response to the reduction of leachate electrical conductivity $\left(\mathrm{dS} \mathrm{m}^{-1}\right)$ during the recovery period (15 September-31 October 2016). 
Based on the $\mathrm{EC}_{\mathrm{L}}$ values required for GTC to reach a $50 \%$ level, the following sequence was evident: "Platinum TE"-15 cm > "Marina" $-15 \mathrm{~cm}>$ "Platinum TE"- $7.5 \mathrm{~cm}$ > "Marina" $-7.5 \mathrm{~cm}$ with estimated $\mathrm{EC}_{\mathrm{L}}$ values of $57.0 \mathrm{dS} \mathrm{m}^{-1}, 46.9 \mathrm{dS} \mathrm{m}^{-1}, 42.3 \mathrm{dS} \mathrm{m}^{-1}$, and $35.6 \mathrm{dS} \mathrm{m}^{-1}$, respectively. A similar categorization was observed in relation to the breakpoint between the two-line segments, representing the $\mathrm{EC}_{\mathrm{L}}$ threshold value below which GTC remains above approximately $90 \%$. These results indicate that, compared with "Marina", "Platinum TE" exhibited an improved capacity to recover through irrigation with potable water after a short period of seawater irrigation when grown in shallow green roof substrates. Considering that Gaetani et al. [23] reported an identical ground coverage rate between "Platinum TE" and "Marina", during both establishment and spring green-up, the differences attested in the current study between the two varieties during the recovery period can be attributed to their different salinity tolerance. The positive effect observed after increasing the substrate depth from $7.5 \mathrm{~cm}$ to $15 \mathrm{~cm}$ during the recovery of the two seashores paspalum varieties may relate to their adaptive mechanism responsible for overcoming salinity stress. Several researchers have reported that seashore paspalum exhibited increased root growth under intermediate levels of salinity [53-55]. It is possible that this mechanism, which relies on an increase of the root absorbing area in search of water and nutrients, might have favored the production of more roots and rhizomes in the deeper profiles of $15 \mathrm{~cm}$ compared with the substrate depth of $7.5 \mathrm{~cm}$, thus improving the ability of seashore paspalum to emerge from dormancy and recover from salt damage.

\section{Conclusions}

To our knowledge, this is the first study that has investigated the response of seashore paspalum to seawater irrigation when grown in shallow green roof systems. At the end of the 46-d stress period, none of the seawater irrigation regimes managed to maintain the GTC of the two seashore paspalum varieties above the threshold value of 50\%. However, based on our research, if seawater has to be selected as the only irrigation source for shallow green roof systems, then a variable approach is recommended. For short time periods, up to 3 weeks, seawater irrigation should be applied at low depths which will result in a slower $\mathrm{EC}_{\mathrm{L}}$ increase and GTC values maintained over $50 \%$. On the contrary, if irrigation with seawater has to be applied for longer periods, it should be applied at the highest possible depth in order to maintain $\mathrm{EC}_{\mathrm{L}}$ close to seawater salinity and minimize turfgrass salinity stress. Cyclic irrigation or blending seawater with other water sources, such as recycled water, brackish water, or harvested rainwater, before irrigation applications may be an option to reduce the salt load to manageable levels. The increase of substrate depth from $7.5 \mathrm{~cm}$ to $15 \mathrm{~cm}$ had a positive effect on the green coverage of the two varieties delaying GTC reduction below $80 \%$ or $50 \%$ by 4 days for "Marina" and 6 days for "Platinum TE".

During the recovery period, while using potable water for turfgrasses irrigation, "Platinum TE" exhibited a better capacity to recover from salt stress than "Marina". Even so, both varieties recorded GTC levels exceeding $90 \%$ in all treatments after 40 days of recovery.

The electrical conductivity of the green roof drainage water was affected by both seawater irrigation regimes and substrate depth. The higher irrigation regime, which resulted in an $\mathrm{LF}$ close to 0.9 , managed to maintain a stable $\mathrm{EC}_{\mathrm{L}}$ that was almost equal to the salinity of seawater. In the $15 \mathrm{~cm}$ substrate depth, a delayed increase of $\mathrm{EC}_{\mathrm{L}}$ by 8 days to seawater salinity levels was observed compared to the $7.5 \mathrm{~cm}$ substrate depth.

Since $\mathrm{EC}_{\mathrm{L}}$ was proven to be a significant predictor of GTC during the stress period, threshold $\mathrm{EC}_{\mathrm{L}}$ values, indicating salinities at which GTC starts to decline, could be used in the estimation of leaching requirements for turfgrasses grown on shallow green roof systems and irrigated with saline water. Relatively inexpensive portable EC meters positioned at the outlets of green roofs could be used for $\mathrm{EC}_{\mathrm{L}}$ monitoring while GTC could easily be determined through non-destructive methods for turfgrasses, such as digital image analysis. Regression curves depicting GTC response to the salinity of drainage water can be used as a decision-making tool for turfgrass and green roof managers. 
Author Contributions: Conceptualization, N.N.; methodology, N.N.; validation, N.N.; formal analysis, N.N.; investigation, N.N.; resources, N.N. and I.V.; data curation, N.N. and I.V.; writing-original draft preparation, N.N.; writing-review and editing, N.N.; visualization, N.N.; supervision, N.N. All authors have read and agreed to the published version of the manuscript.

Funding: This research received no external funding.

Acknowledgments: The authors would like to thank HellaSod S.A. for donating the "Platinum TE" seashore paspalum sod and Agrostis G.P. for donating the "Marina" seashore paspalum sod.

Conflicts of Interest: The authors declare no conflict of interest.

\section{References}

1. Fernandez-Cañero, R.; Emilsson, T.; Fernandez-Barba, C.; Machuca, M.Á.H. Green roof systems: A study of public attitudes and preferences in southern Spain. J. Environ. Manag. 2013, 128, 106-115. [CrossRef] [PubMed]

2. Savi, T.; Andri, S.; Nardini, A. Impact of different green roof layering on plant water status and drought survival. Ecol. Eng. 2013, 57, 188-196. [CrossRef]

3. Bousselot, J.M.; Klett, J.E.; Koski, R.D. Moisture content of extensive green roof substrate and growth response of 15 temperate plant species during dry down. HortScience 2011, 46, 518-522. [CrossRef]

4. Nektarios, P.A.; Ntoulas, N.; Nydrioti, E.; Kokkinou, I.; Bali, E.-M.; Amountzias, I. Drought stress response of Sedum sediforme grown in extensive green roof systems with different substrate types and depths. Sci. Hortic. 2015, 181, 52-61. [CrossRef]

5. Beard, J.B.; Green, R.L. The role of turfgrasses in environmental protection and their benefits to humans. J. Environ. Qual. 1994, 23, 452-460. [CrossRef]

6. Ntoulas, N.; Nektarios, P.A.; Kotopoulis, G.; Ilia, P.; Ttooulou, T. Quality assessment of three warm-season turfgrasses growing in different substrate depths on shallow green roof systems. Urban For. Urban Green. 2017, 26, 163-168. [CrossRef]

7. Ntoulas, N.; Nektarios, P.A.; Nydrioti, E. Performance of Zoysia matrella 'Zeon' in shallow green roof substrates under moisture deficit conditions. HortScience 2013, 48, 929-937. [CrossRef]

8. Ntoulas, N.; Nektarios, P.A.; Charalambous, E.; Psaroulis, A. Zoysia matrella cover rate and drought tolerance in adaptive extensive green roof systems. Urban For. Urban Green. 2013, 12, 522-531. [CrossRef]

9. Nektarios, P.; Ntoulas, N.; Kotopoulis, G.; Ttoulou, T.; Ilia, P. Festuca arundinacea drought tolerance and evapotranspiration when grown on two extensive green roof substrate depths and under two irrigation regimes. Eur. J. Hortic. Sci. 2014, 79, 142-149.

10. Ntoulas, N.; Nektarios, P.A. Paspalum vaginatum drought tolerance and recovery in adaptive extensive green roof systems. Ecol. Eng. 2015, 82, 189-200. [CrossRef]

11. Ntoulas, N.; Nektarios, P.A. Paspalum vaginatum NDVI when grown on shallow green roof systems and under moisture deficit conditions. Crop Sci. 2017, 57, S-147-S-160. [CrossRef]

12. Marcum, K.B. Use of saline and non-potable water in the turfgrass industry: Constraints and developments. Agric. Water Manag. 2006, 80, 132-146. [CrossRef]

13. Moritani, S.; Yamamoto, T.; Andry, H.; Inoue, M.; Kato, K.; Saito, H. Effect of combined water and salinity stress factors on evapotranspiration of Sedum kamtschaticum Fischer in relation to green roof irrigation. Urban For. Urban Green. 2013, 12, 338-343. [CrossRef]

14. Agra, H.; Solodar, A.; Bawab, O.; Levy, S.; Kadas, G.J.; Blaustein, L.; Greenbaum, N. Comparing grey water versus tap water and coal ash versus perlite on growth of two plant species on green roofs. Sci. Total Environ. 2018, 633, 1272-1279. [CrossRef] [PubMed]

15. Stratigea, D.; Makropoulos, C. Balancing water demand reduction and rainfall runoff minimisation: Modelling green roofs, rainwater harvesting and greywater reuse systems. Water Sci. Technol. Water Supply 2015, 15, 248-255. [CrossRef]

16. Schaan, C.M.; Devitt, D.; Morris, R.; Clark, L. Cyclic irrigation of turfgrass using a shallow saline aquifer. Agron. J. 2003, 95, 660-667. [CrossRef]

17. Schiavon, M.; Leinauer, B.; Serena, M.; Sallenave, R.; Maier, B. Bermudagrass and seashore paspalum establishment from seed using differing irrigation methods and water qualities. Agron. J. 2012, 104, 706-714. [CrossRef]

18. Serena, M.; Leinauer, B.; Schiavon, M.; Maier, B.; Sallenave, R. Establishment and rooting response of bermudagrass propagated with saline water and subsurface irrigation. Crop Sci. 2014, 54, 827-836. [CrossRef]

19. Sevostianova, E.; Leinauer, B.; Sallenave, R.; Karcher, D.; Maier, B. Soil salinity and quality of sprinkler and drip irrigated warm-season turfgrasses. Agron. J. 2011, 103, 1773-1784. [CrossRef]

20. Carrow, R.N.; Duncan, R.R.; Huck, M.T. Turfgrass and Landscape Irrigation Water Quality: Assessment and Management, 1st ed.; CRC Press: Boca Raton, FL, USA, 2009.

21. Duncan, R.R.; Carrow, R.N.; Huck, M.T. Effective use of seawater irrigation on turfgrass. USGA Green Sect. Rec. $2000,38,11-17$.

22. Borghini, M.; Bryden, H.; Schroeder, K.; Sparnocchia, S.; Vetrano, A. The Mediterranean is becoming saltier. Ocean Sci. 2014, 10, 693-700. [CrossRef] 
23. Gaetani, M.; Volterrani, M.; Magni, S.; Caturegli, L.; Minelli, A.; Leto, C.; La Bella, S.; Tuttolomondo, T.; Virga, G.; Grossi, N. Seashore paspalum in the Mediterranean transition zone: Phenotypic traits of twelve accessions during and after establishment. Ital. J. Agron. 2017, 12, 110-115. [CrossRef]

24. Huang, B.; Duncan, R.R.; Carrow, R.N. Drought-resistance mechanisms of seven warm-season turfgrasses under surface soil drying: I. Shoot response. Crop Sci. 1997, 37, 1858-1863. [CrossRef]

25. Lee, G.; Carrow, R.N.; Duncan, R.R. Growth and water relation responses to salinity stress in halophytic seashore paspalum ecotypes. Sci. Hortic. 2005, 104, 221-236. [CrossRef]

26. Trenholm, L.E.; Duncan, R.R.; Carrow, R.N. Wear tolerance, shoot performance, and spectral reflectance of seashore paspalum and bermudagrass. Crop Sci. 1999, 39, 1147-1152. [CrossRef]

27. Lee, G.; Duncan, R.R.; Carrow, R.N. Salinity tolerance of seashore paspalum ecotypes: Shoot growth responses and criteria. HortScience 2004, 39, 1138-1142. [CrossRef]

28. Carrow, R.R.; Huck, M.T.; Duncan, R.R. Leaching for salinity management on turfgrass sites. USGA Green Sect. Rec. 2000, 38, $15-24$.

29. Rhoades, J. Drainage for salinity control. In Drainage for Agriculture; van Schilfgaarde, J., Ed.; SSSA: Madison, WI, USA, 1974; Volume 17, pp. 433-461. [CrossRef]

30. Kokkinou, I.; Ntoulas, N.; Nektarios, P.A.; Varela, D. Response of native aromatic and medicinal plant species to water stress on adaptive green roof systems. HortScience 2016, 51, 608-614. [CrossRef]

31. Kotsiris, G.; Nektarios, P.A.; Ntoulas, N.; Kargas, G. An adaptive approach to intensive green roofs in the Mediterranean climatic region. Urban For. Urban Green. 2013, 12, 380-392. [CrossRef]

32. Ntoulas, N.; Nektarios, P.A.; Spaneas, K.; Kadoglou, N. Semi-extensive green roof substrate type and depth effects on Zoysia matrella 'Zeon' growth and drought tolerance under different irrigation regimes. Acta Agric. Scand. B Soil Plant Sci. 2012, 62, 165-173. [CrossRef]

33. Ntoulas, N.; Nektarios, P.A.; Kapsali, T.-E.; Kaltsidi, M.-P.; Han, L.; Yin, S. Determination of the physical, chemical, and hydraulic characteristics of locally available materials for formulating extensive green roof substrates. Horttechnology 2015, 25, 774-784. [CrossRef]

34. Richardson, M.; Karcher, D.; Purcell, L. Quantifying turfgrass cover using digital image analysis. Crop Sci. 2001, 41, 1884-1888. [CrossRef]

35. Motulsky, H.J.; Christopoulos, A. Fitting Models to Biological Data Using Linear and Nonlinear Regression: A Practical Guide to Curve Fitting; GraphPad Software Inc.: San Diego, CA, USA, 2003.

36. Cathey, S.E.; Kruse, J.K.; Sinclair, T.R.; Dukes, M.D. Transpiration and visual appearance of warm season turfgrasses during soil drying. Environ. Exp. Bot. 2013, 89, 36-43. [CrossRef]

37. VanWoert, N.D.; Rowe, D.B.; Andresen, J.A.; Rugh, C.L.; Fernandez, R.T.; Xiao, L. Green roof stormwater retention: Effects of roof surface, slope, and media depth. J. Environ. Qual. 2005, 34, 1036-1044. [CrossRef] [PubMed]

38. Yilmaz, D.; Sabre, M.; Lassabatere, L.; Dal, M.; Rodriguez, F. Storm water retention and actual evapotranspiration performances of experimental green roofs in French oceanic climate. Eur. J. Environ. Civ. Eng. 2016, 20, 344-362. [CrossRef]

39. Soulis, K.X.; Ntoulas, N.; Nektarios, P.A.; Kargas, G. Runoff reduction from extensive green roofs having different substrate depth and plant cover. Ecol. Eng. 2017, 102, 80-89. [CrossRef]

40. Miyamoto, S.; Glenn, E.P.; Olsen, M.W. Growth, water use and salt uptake of four halophytes irrigated with highly saline water. J. Arid Environ. 1996, 32, 141-159. [CrossRef]

41. Vesuviano, G.; Stovin, V. A generic hydrological model for a green roof drainage layer. Water Sci. Technol. 2013, 68, 769-775. [CrossRef]

42. El-Haddad, E.-S.H.; Noaman, M.M. Leaching requirement and salinity threshold for the yield and agronomic characteristics of halophytes under salt stress. J. Arid Environ. 2001, 49, 865-874. [CrossRef]

43. Chowdhury, R.K.; Abaya, J.S. An experimental study of greywater irrigated green roof systems in an arid climate. J. Water Manag. Model. 2018, 26, 1-10. [CrossRef]

44. Lee, G.; Carrow, R.N.; Duncan, R.R. Criteria for assessing salinity tolerance of the halophytic turfgrass seashore paspalum. Crop Sci. 2005, 45, 251-258. [CrossRef]

45. Marcum, K.B. Salinity tolerance mechanisms of grasses in the subfamily Chloridoideae. Crop Sci. 1999, 39, 1153-1160. [CrossRef]

46. Berndt, W.L. Salinity affects quality parameters of 'SeaDwarf' seashore paspalum. HortScience 2007, 42, 417-420. [CrossRef]

47. Pompeiano, A.; Di Patrizio, E.; Volterrani, M.; Scartazza, A.; Guglielminetti, L. Growth responses and physiological traits of seashore paspalum subjected to short-term salinity stress and recovery. Agric. Water Manag. 2016, 163, 57-65. [CrossRef]

48. Uddin, M.K.; Juraimi, A.S.; Ismail, M.R.; Hossain, M.A.; Othman, R.; Abdul Rahim, A.A. Physiological and growth responses of six turfgrass species relative to salinity tolerance. Sci. World J. 2012, 905468. [CrossRef]

49. Shahba, M.A. Comparative responses of bermudagrass and seashore paspalum cultivars commonly used in Egypt to combat salinity stress. Hortic. Environ. Biotechnol. 2010, 51, 383-390. [CrossRef]

50. Marcum, K.B.; Murdoch, C.L. Growth responses, ion relations, and osmotic adaptations of eleven C4 turfgrasses to salinity. Agron. J. 1990, 82, 892-896. [CrossRef]

51. Lee, G.; Carrow, R.N.; Duncan, R.R. Salinity tolerance of selected seashore paspalums and bermudagrasses: Root and verdure responses and criteria. HortScience 2004, 39, 1143-1147. [CrossRef] 
52. Maas, E.V.; Hoffman, G.J. Crop salt tolerance-current assessment. J. Irrig. Drain. Div. 1977, 103, 115-134.

53. Guo, H.; Wang, Y.; Li, D.; Chen, J.; Zong, J.; Wang, Z.; Chen, X.; Liu, J. Growth response and ion regulation of seashore paspalum accessions to increasing salinity. Environ. Exp. Bot. 2016, 131, 137-145. [CrossRef]

54. Pessarakli, M.; Breshears, D.D.; Walworth, J.; Field, J.P.; Law, D.J. Candidate halophytic grasses for addressing land degradation: Shoot responses of Sporobolus airoides and Paspalum vaginatum to weekly increasing $\mathrm{NaCl}$ concentration. Arid Land Res. Manag. 2017, 31, 169-181. [CrossRef]

55. Shahba, M.A.; Alshammary, S.F.; Abbas, M.S. Effects of salinity on seashore paspalum cultivars at different mowing heights. Crop Sci. 2012, 52, 1358-1370. [CrossRef] 